\title{
Van startende kunstenaar tot gevorderde
}

Citation for published version (APA):

Allen, J., Belfi, B., \& Mommers, A. (2017). Van startende kunstenaar tot gevorderde: De loopbaanontwikkeling van kunstenaars in de eerste vijf jaren na afstuderen. ROA. ROA Reports No. 006 https://doi.org/10.26481/umarep.2017006

Document status and date:

Published: 01/01/2017

DOI:

10.26481/umarep.2017006

\section{Please check the document version of this publication:}

- A submitted manuscript is the version of the article upon submission and before peer-review. There can be important differences between the submitted version and the official published version of record.

People interested in the research are advised to contact the author for the final version of the publication, or visit the DOI to the publisher's website.

- The final author version and the galley proof are versions of the publication after peer review.

- The final published version features the final layout of the paper including the volume, issue and page numbers.

Link to publication

\footnotetext{
General rights rights.

- You may freely distribute the URL identifying the publication in the public portal. please follow below link for the End User Agreement:

www.umlib.nl/taverne-license

Take down policy

If you believe that this document breaches copyright please contact us at:

repository@maastrichtuniversity.nl

providing details and we will investigate your claim.
}

Copyright and moral rights for the publications made accessible in the public portal are retained by the authors and/or other copyright owners and it is a condition of accessing publications that users recognise and abide by the legal requirements associated with these

- Users may download and print one copy of any publication from the public portal for the purpose of private study or research.

- You may not further distribute the material or use it for any profit-making activity or commercial gain

If the publication is distributed under the terms of Article $25 \mathrm{fa}$ of the Dutch Copyright Act, indicated by the "Taverne" license above, 


\section{Van startende kunstenaar tot gevorderde De loopbaanontwikkeling van kunstenaars in de eerste vijf jaren na afstuderen}

\section{ROA Rapport}

ROA-R-2017/6

Researchcentrum voor Onderwijs en Arbeidsmarkt | ROA Research Centre for Education and the Labour Market / ROA 


\section{VAN STARTENDE KUNSTENAAR TOT GEVORDERDE}

De loopbaanontwikkeling van kunstenaars

in de eerste vijf jaren na afstuderen

ROA-R-2017/6

Jim Allen

Barbara Belfi

Ardi Mommers 


\section{Colofon}

(C) Researchcentrum voor Onderwijs en Arbeidsmarkt (ROA). Niets uit deze uitgave mag op enige manier worden verveelvoudigd zonder voorafgaande schriftelijke toestemming van de directeur van het ROA.

\section{Researchcentrum voor Onderwijs en Arbeidsmarkt}

School of Business and Economics

Maastricht University

email: secretary-roa-sbe@maastrichtuniversity.nl

website: www.roa.nl

\section{Vormgeving}

ROA secretariaat, Maastricht

ISBN: 978-90-5321-559-3

juli 2017 


\section{INHOUD}

\section{Samenvatting}

1 Inleiding

1.1 Onderzoeksopzet en respons

2 Ontwikkelingen in arbeidsmarktpositie

2.1 Werkloosheid

2.2 Aantal werkgevers

2.3 Aansluiting opleiding-werk

2.4 Type dienstverband 11

$\begin{array}{ll}2.5 & \text { Lonen } \\ & 15\end{array}$

2.6 Carrièremogelijkheden huidige functie (2015) 17

2.7 Tevredenheid huidige functie (2015) 19

2.8 Werkdruk (2015) 20

$3 \quad$ Terugblik op de opleiding 23

3.1 Studietevredenheid (2015) 23

3.2 Voorbereiding studie op loopbaan (2015) 24

3.3 Opnieuw kiezen voor opleiding 26

4 Conclusies 


\section{SAMENVATTING}

De Kunsten-Monitor brengt jaarlijks de arbeidsmarktpositie van afgestudeerde kunstenaars, één jaar na diplomering, in kaart. Ook kijken de alumni in de monitor terug naar de door hen gevolgde opleiding. In 2015 is naast de reguliere 'T+1 meting' (één jaar na afstuderen) een aanvullende meting uitgevoerd Het gaat bij deze aanvullende meting om de positie van afgestudeerde kunstenaars vijf c.q. zes jaar na diplomering (' $T+5$ ' c.q. ' $T+6^{\prime}$ ). Aangezien het op de begin- en eindmeting om exact dezelfde groep afgestudeerden gaat, kunnen individuele (loopbaan)ontwikkelingen worden bestudeerd. In totaal zijn er 397 respondenten uit het hbo-kunstonderwijs die op beide meetmomenten deel hebben genomen aan de vragenlijst. De belangrijkste bevindingen van dit onderzoek kunnen als volgt worden samengevat, waarbij de getoonde resultaten betrekking hebben op zowel voltijd- als deeltijdstudenten, tenzij expliciet aangegeven wordt dat het alleen voltijders betreft.

\section{Arbeidsmarktpositie}

- De werkloosheid is tussen 2010/2011 (één jaar na afstuderen) en 2015 (vijf/zes jaar na afstuderen) gegroeid van 3,0 procent naar 6,1 procent. Hbo-breed is daarentegen sprake van een lichte daling van 3,6 procent naar 3,1 procent.

- Sinds het moment van diplomering hebben vrijwel alle afgestudeerde kunstenaars op een bepaald moment een baan gehad. De helft van de voltijdstudenten (51\%) heeft drie of meer werkgevers gehad: relatief hoog ten opzichte van het hbobrede gemiddelde van 38 procent (voltijders). Vooral afgestudeerden van Theateropleidingen zijn vaak van werkgever veranderd.

- Het aandeel afgestudeerden uit de kunstenopleidingen dat een baan op minimaal hbo-niveau heeft, is tussen 2010/2011 en 2015 toegenomen met 6 procentpunten (van $72 \%$ naar $78 \%$ ). Van alle kunstenaars, zijn musici in 2015 het vaakst werkzaam op hbo-niveau.

- Het aandeel werkenden op minimaal hbo-niveau én in het eigen vakgebied (oftewel in het 'kerndomein') is sterk toegenomen tussen 2010/2011 en 2015 (van 53\% naar $63 \%)$. Theater-alumni werken het vaakst in het kerndomein.

- Het aandeel afgestudeerden dat (vooral) als zelfstandige werkte, is tussen 2010/2011 en 2015 fors afgenomen (van 51\% naar 39\%). Vergeleken met andere hbo-sectoren is het aandeel zelfstandigen echter nog altijd erg hoog. Met name musici zijn vaak werkzaam als zelfstandige. 
- De bruto uurlonen van afgestudeerde kunstenaars zijn tussen 2010/2011 en 2015 met 27 procent toegenomen. Kunstenaars hebben verhoudingsgewijs een sterkere loongroei doorgemaakt dan het hbo-gemiddelde ( $22 \%$ toename), maar in absolute zin liggen de lonen (zowel in 2010/2011 als) in 2015 wel lager.

\section{Werkbeleving}

- Bijna de helft van de afgestudeerde kunstenaars ervaart anno 2015 veel carrièremogelijkheden in hun baan. Slechts een kwart ervaart (heel) weinig mogelijkheden.

- De baantevredenheid onder afgestudeerde kunstenaars ligt in 2015 op het hoogste niveau van alle hbo-sectoren. Zeven op de tien alumni is tevreden over hun huidige functie.

- Alumni van kunstenopleidingen ervaren in 2015, net als afgestudeerden uit de hbosector Onderwijs, relatief vaak (34\%) een hoge werkdruk. Hbo-breed betreft het ongeveer een kwart.

\section{Terugblik op opleiding}

- In 2015 is twee derde van de afgestudeerde kunstenaars tevreden over de gevolgde opleiding. Dit is vergelijkbaar met het hbo-brede gemiddelde.

- Over de voorbereiding van de studie op de loopbaan is men veel minder tevreden: minder dan drie tiende van de alumni is hier tevreden over. Dit aandeel ligt daarmee fors lager dan hbo-breed (aldaar ruim vier tiende).

- Drie kwart van de afgestudeerde kunstenaars zou in 2015, alles overziend, wederom voor dezelfde opleiding te kiezen als men weer voor de keuze zou staan. Dit is een kleiner aandeel dan in 2010/2011 (toen 85\%), maar nog altijd relatief hoog. 


\section{INLEIDING}

\subsection{Onderzoeksopzet en respons}

De Kunsten-Monitor is een jaarlijks enquêteonderzoek onder afgestudeerde hbo'ers uit het kunstonderwijs dat de transitie van het hbo naar de arbeidsmarkt in kaart brengt. Het onderzoek levert informatie op over de arbeidsmarktpositie van alumni en hun terugblik op de opleiding. De reguliere meting die een jaar na afstuderen $(T+1)$ plaatsvindt, geeft een goed beeld van de initiële overgang naar de arbeidsmarkt. Het is echter ook belangrijk om te weten hoe de loopbaan van afgestudeerden zich verder ontwikkelt en in hoeverre de opleiding hiervoor een goede basis biedt. In 2015 is daarom naast de reguliere $T+1$ meting een aanvullende meting uitgevoerd enkele jaren na afstuderen. De hbo-brede, landelijke resultaten zijn reeds gepubliceerd in het rapport Van starter tot gevorderde en zijn gebaseerd op gekoppelde gegevens (op persoonsniveau) van één jaar na afstuderen met gegevens vijf jaar na afstuderen. Het betreft dus dezelfde personen die op twee momenten bevraagd zijn, waardoor individuele loopbaanontwikkelingen geschetst kunnen worden. Voorliggend rapport is een aanvulling op de hbo-brede rapportage, en richt zich specifiek op afgestudeerden uit de hbo-kunstenopleidingen. Omdat het aantal kunstenafgestudeerden van de $\mathrm{T}+5$ meting te klein is om gespecificeerde analyes op uit voeren, hebben we ervoor gekozen om voor de huidige analyses zowel gegevens te benutten van afgestudeerde kunstenaars vijf jaar na afstuderen als zes jaar na afstuderen, oftewel ' $T+5$ ' en ' $T+6$ '. Beide groepen zijn bevraagd in 2015, maar voor het ene deel van de respondenten vond de oorspronkelijke T+1-meting plaats in 2010 en voor het andere deel in 2011. Kortom: we vergelijken in deze rapportage de situatie vijfc.q. zes jaar na afstuderen met de situatie één jaar na afstuderen². Daar waar we vergelijkingen maken met andere hbo-sectoren gaat het eveneens om gegevens uit ' $T+1$ ' enerzijds en de gecombineerde ' $T+5$ ' en ' $T+6$ ' gegevens anderzijds, hierdoor kunnen de hbo-brede en hbo-sectorale cijfers licht afwijken van het eerdere gepubliceerde rapport ${ }^{3}$.

Het is voor 397 afgestudeerden uit het kunstenonderwijs mogelijk gebleken om hun gegevens uit 2010/2011 (één jaar na afstuderen) te koppelen met de gegevens uit 2015

1 http://roa.sbe.maastrichtuniversity.nl/roanew/wp-content/uploads/2014/o2/ROA_R_2016_6.pdf

2 De vergelijking tussen 2010/2011 en 2015 is niet altijd mogelijk, voor een aantal indicatoren zijn alleen gegevens uit 2015 voorradig. In dat geval presenteren we de gegevens uit 2015.

3 Hbo-breed betreft het aantal respondenten met twee metingen $(T+1$ en $T+5 / T+6) 4.985$. 
(vijf c.q. zes jaar na afstuderen). De helft van hen (51\%) is afkomstig uit de subsector Beeldende Kunst. De andere helft bestaat uit afgestudeerden uit de subsectoren Muziek (16\%), Theater (9\%), Creatieve Industrie Techniek (12\%) en overige opleidingen ${ }^{4}(12 \%)$. Bijna de helft van de kunsten-alumni (47\%) is afgestudeerd in 2009 en de andere helft $(53 \%)$ in $2010^{5}$. Negen op de tien respondenten (88\%) waren voltijdstudent en één op de tien $(12 \%)$ deeltijdstudent ${ }^{6}$.

4 Onder andere dansopleidingen, opleiding Cultureel erfgoed enz.

Deze verhoudingen zijn vergelijkbaar voor de verschillende subsectoren.

6 De deeltijdstudenten zijn grotendeels afkomstig uit de Beeldende Kunst. Er zijn geen verschillen in de verhouding voltijd/deeltijd tussen 2009 en 2010. 


\section{ONTWIKKELINGEN IN ARBEIDSMARKTPOSITIE}

\subsection{Werkloosheid}

Tussen 2010/2011 (één jaar na diplomering) en 2015 (vijf c.q. zes jaar na diplomering) steeg de werkloosheid in de hbo-sector Kunst van 3,0 procent naar 6,1 procent (Figuur 2.1) ${ }^{7}$. Hbo-breed nam de werkloosheid juist licht af van 3,6 procent naar 3,1 procent. De verdubbeling van de werkloosheid onder afgestudeerden van kunstenopleidingen heeft vermoedelijk te maken met de forse bezuinigingen die de cultuursector vanaf 2013 hebben getroffen ${ }^{8}$. Ook in de jaren daarvoor was de cultuursector overigens al fors gekrompen. Zo concludeert de Commissie Arbeidsmarktverkenning Cultuursector $\left(2016^{\circ}\right)$ dat het aantal banen van werknemers in de cultuursector tussen 2009 en 2013 sterk is gedaald. "In de periode 2009 tot en met 2013 zijn in de culturele sector circa 20 duizend banen van werknemers verloren gegaan, waarvan de helft in 2013. De daling van het aantal banen van werknemers in de culturele sector geldt voor elk van de drie domeinen die het CBS onderscheidt: kunsten en erfgoed (-12,3 procent); media \& entertainment (-11,1 procent); creatieve zakelijke dienstverlening (-13,6 procent)." (p.10)

Uit nadere analyses die hier niet zijn getoond, bleek verder dat de werkloosheid vooral is toegenomen onder afgestudeerden van deeltijdopleidingen. Dit is verklaarbaar aangezien deeltijders hun opleiding (vaak) combineren met een baan. Waar voor hen de uitgangspositie tijdens de opleiding 'werk' is, is de uitgangpositie voor voltijdstudenten (meestal) juist 'geen werk'. In die zin kunnen voltijdstudenten er in de jaren na afstuderen doorgaans alleen maar op 'vooruit' gaan, terwijl deeltijdstudenten juist iets 'te verliezen' hebben.

$7 \quad$ Tot de werkzame beroepsbevolking behoort iedereen die minstens één uur per week betaald werk verricht. Mensen die geen betaald werk hebben maar hier wel naar op zoek zijn vormen de werkloze beroepsbevolking.

8 "De rijksoverheid bezuinigt conform het regeerakkoord van het kabinet Rutte I met ingang van 2013 in totaal 200 miljoen euro op de culturele sector. Deze bezuiniging is deels ingevuld door het stopzetten van subsidieregelingen en andere posten. Ook is er een generieke bezuiniging op de gehele cultuurbegroting doorgevoerd van 2,2\% incidenteel in 2011 en 5\% structureel vanaf 2012." Kamerbrief OCW, 24 december 2013.

9 Commissie Arbeidsmarktverkenning Cultuursector (2016). Verkenning arbeidsmarkt culturele sector. Den Haag: Sociaal-Economische Raad; Raad voor Cultuur. 
FIGUUR 2.1 Werkloosheid in 2010-2011 en 2015

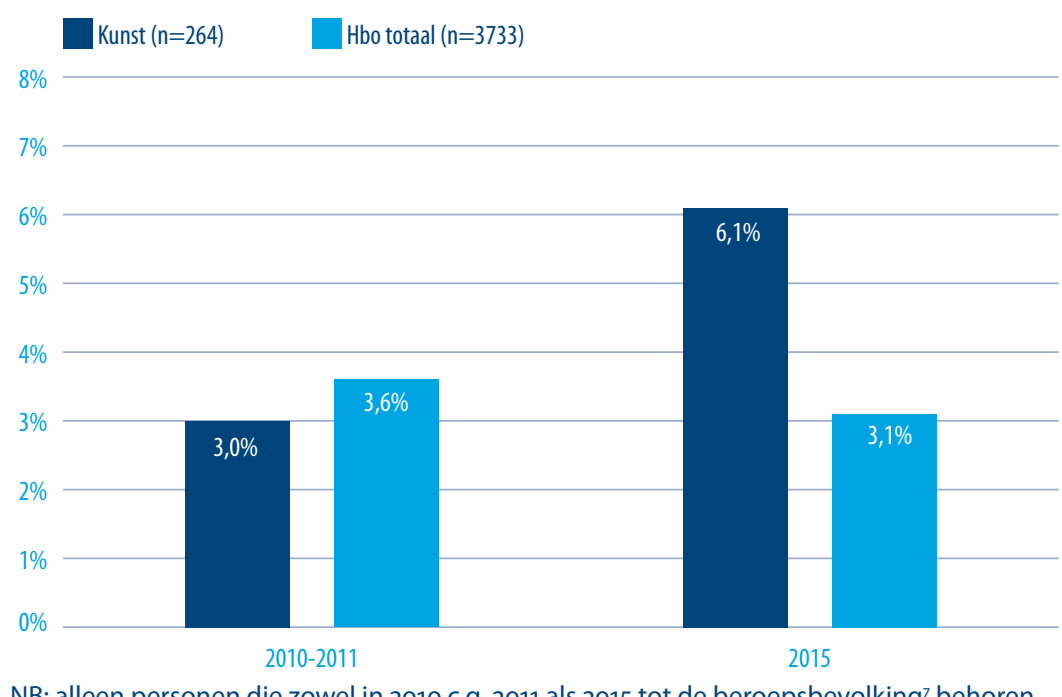

NB: alleen personen die zowel in 2010 c.q. 2011 als 2015 tot de beroepsbevolking 7 behoren

\subsection{Aantal werkgevers}

Sinds het moment van afstuderen hebben vrijwel alle afgestudeerde kunstenaars op een bepaald moment een baan gehad. Slechts 2 procent geeft in 2015 aan geen werkgevers te hebben gehad. De helft van de afgestudeerden heeft vijf/zes jaar na afstuderen minstens drie werkgevers gehad, één op de vijf afgestudeerden heeft zelfs vijf of meer werkgevers gehad ${ }^{10}$. De mobiliteit onder afgestudeerde kunstenaars (voltijdstudenten) is relatief hoog, zo blijkt uit Figuur 2.2. In de andere hbo-sectoren ligt het aandeel afgestudeerden dat minstens drie werkgevers had namelijk tussen de 27 procent (Bètatechniek) en 44 procent (Sociale Studies). Hbo-breed heeft 38 procent van de afgestudeerde voltijdstudenten minstens drie werkgevers gehad.

De relatief hoge mate van werkgeversveranderingen binnen de kunstsector kan voor een deel toegeschreven worden aan tijdelijke en projectmatige aanstellingen. De Commissie Arbeidsmarktverkenning Cultuursector (2016) signaleert relatief veel tijdelijke dienstverbanden en werkenden op oproepbasis in de cultuursector, omdat culturele instellingen vanwege het vaak projectgebonden en/of -specialistische werk vaak terughoudend zijn om mensen in vaste dienst te nemen.

Het veranderen van werkgever kan voor kunstenaars echter ook positieve effecten hebben. Zo stimuleert de Europese Commissie (2017'1) (internationale) beroepsmobili-

10 Indien men (ook) als zelfstandige heeft gewerkt, telt dit mee als één afzonderlijke werkgever.

11 Zie EURES: Het Europees Portaal Voor Beroepsmobiliteit op https://ec.europa.eu/eures/public/nl/homepage. afgestudeerden uit kunstenopleidingen, anderaan wat minder sterk is voor de $\mathrm{n}$ 2010/2011 betrof het $\mathrm{n}$ gen. ( ( naar niveau en/of $r$ 
teit onder kunstenaars actief, omdat "mobiliteit en uitwisseling voor regionale artiesten een mogelijke 'opening' [is] naar een breder publiek en dus naar een grotere markt. [...] Mobiliteit houdt echter ook netwerkvorming in, en verblijfplaatsen voor kunstenaars in verschillende $[\ldots]$ steden."

FIGUUR 2.2 Percentage afgestudeerden met 3 of meer werkgevers, inclusief huidige werkgever, in 2015, naar hbo-sector, voltijd $(n=3604)$

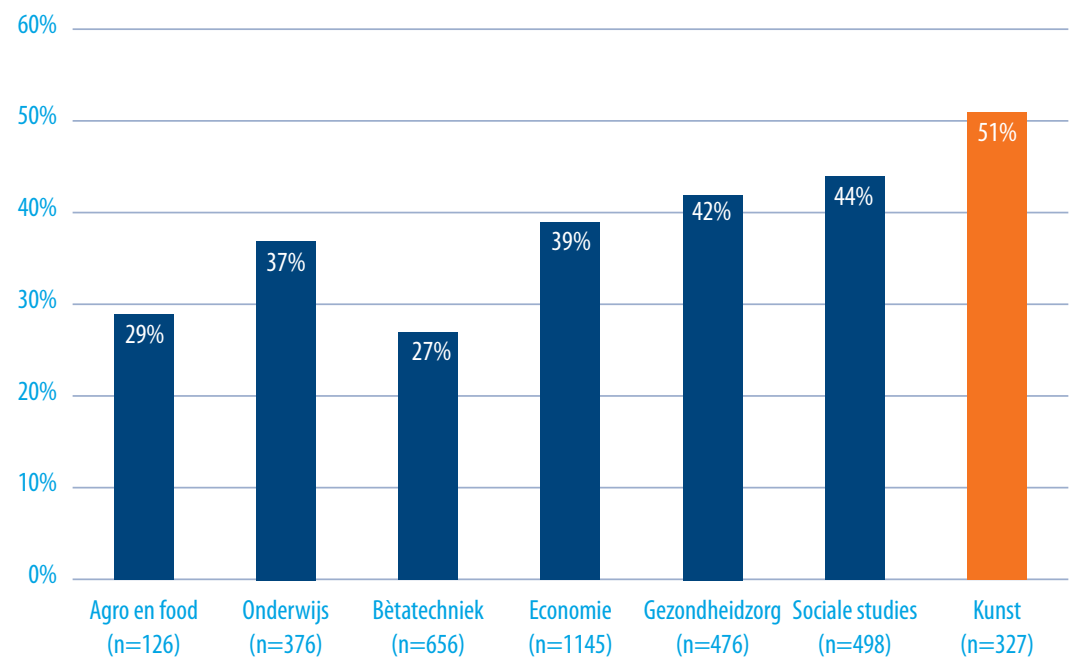

Figuur 2.3 laat zien dat er grote verschillen zijn in de mate van verandering van werkgevers tussen de diverse subsectoren van het kunstonderwijs. De subsector Theater springt vooral in het oog: negen op de tien afgestudeerden (86\%) hebben in 2015 minstens drie werkgevers gehad. Uit nadere analyse op deze subsector volgt dat met name afgestudeerden in de richtingen 'acteur' en 'theatermaker' erg mobiel zijn ${ }^{12}$. Waarschijnlijk heeft dit te maken met frequente projectmatige aanstellingen. Ook is het denkbaar dat mobiliteit binnen de theaterwereld relatief belangrijk(er) is om naamsbekendheid op te bouwen. In de andere subsectoren ligt de mobiliteit veel lager. Zo heeft 43 procent van de alumni uit de Beeldende Kunst drie of meer werkgevers gehad.

12 Ten opzichte van afgestudeerden uit de theaterrichtingen 'docent drama' en 'theatermanagement'. 
FIGUUR 2.3 Percentage afgestudeerden met 3 of meer werkgevers, inclusief huidige werkgever, in 2015 , naar subsector, voltijd $(n=327)$

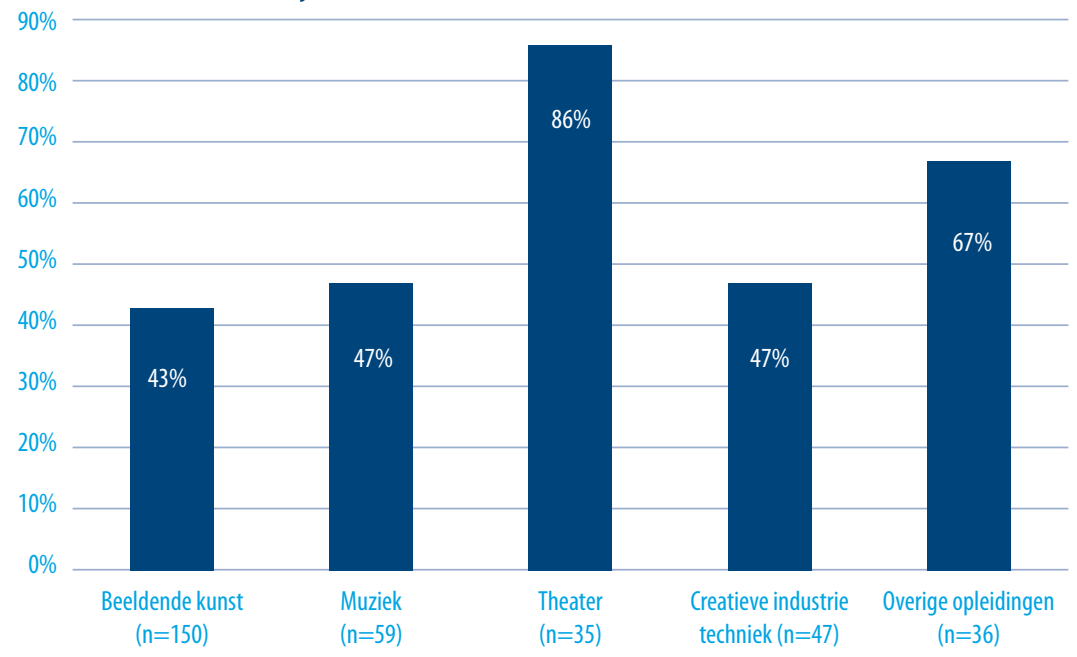

\subsection{Aansluiting opleiding-werk}

Figuur 2.5 toont in hoeverre er een aansluiting is tussen opleiding en werk wat betreft het (voor de functie) gevraagde opleidingsniveau en de gevraagde opleidingsrichting. We zien dat 53 procent van de afgestudeerde kunstenaars één jaar na diplomering een baan in het zogenaamde 'kerndomein' had gevonden. Dat wil zeggen: een baan die zowel qua opleidingsniveau als opleidingsrichting aansluit op de hbo-opleiding. In 2015 (vijf/zes jaar na afstuderen) is dit aandeel fors toegenomen tot 63 procent. Na enkele jaren op de arbeidsmarkt hebben afgestudeerde kunstenaars dus vaker een baan op het eigen opleidingsniveau én in de eigen richting. Als we kijken naar het aandeel afgestudeerden dat in ieder geval op hbo-niveau of hoger werkt, dan is er sprake van een toename van 72 procent naar 78 procent.

Het aandeel afgestudeerde kunstenaars dat een baan op hbo-niveau (of hoger) had, maar niet in de eigen richting is tussen 2010/2011 en 2015 afgenomen van 19 procent naar 15 procent. Het aandeel afgestudeerden dat wel een baan in het eigen vakgebied had, maar ónder hbo-niveau, is meer dan gehalveerd tussen 2010/2011 en 2015: van 14 procent naar 6 procent. Het percentage kunstenaars dat ónder niveau en buiten de eigen richting werkte is ruwweg stabiel gebleven (12\% en $11 \%)$.

Concluderend is het aandeel afgestudeerde kunstenaars dat tussen 2010/2011 en 2015 een beter passende baan (naar niveau en/of richting) heeft gevonden fors toegenomen. Tegelijkertijd is er in 2015 nog steeds een behoorlijke groep dat buiten het kerndomein werkt (en is een klein aandeel werkloos). 
FIGUUR 2.4 Is functie minimaal op hbo-niveau en in eigen richting, in 2010-2011 en 2015 ( $n=240)$

Minimaal hbo-niveau, eigen/verwante richting

Onder hbo-niveau, eigen/verwante richting
Minimaal hbo-niveau, geen/andere richting

Onder hbo-niveau, geen/andere richting

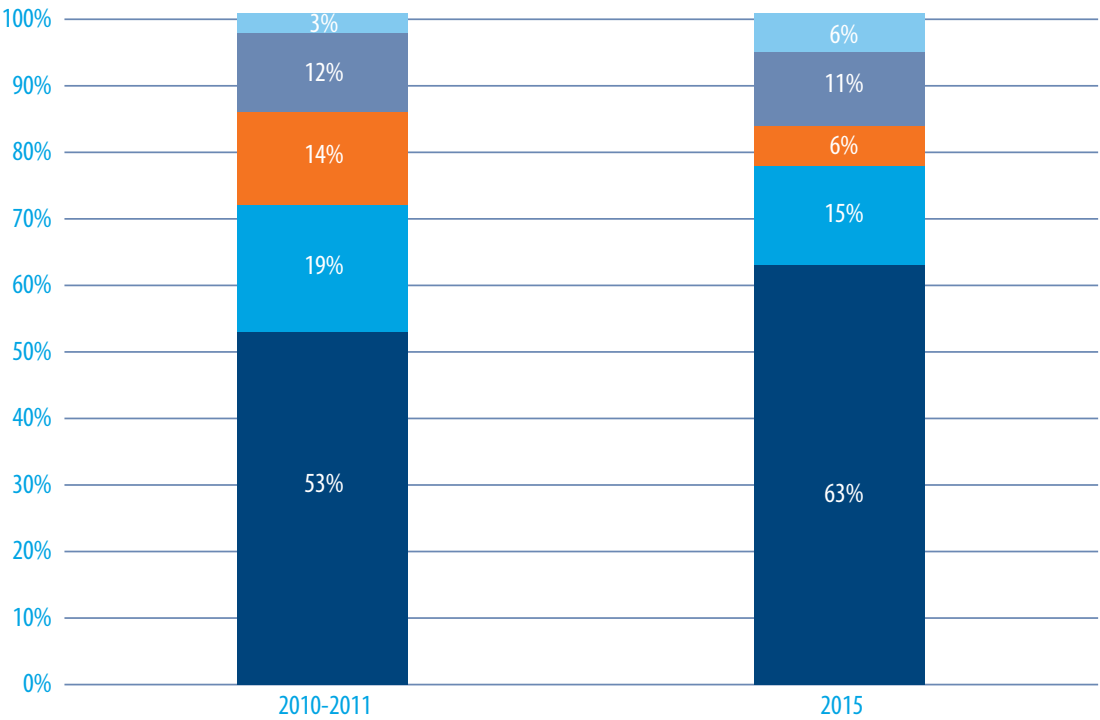

NB: Alleen respondenten die in 2010 c.q. 2011 en in 2015 tot beroepsbevolking behoorden

Ook hbo-breed is het aandeel werkenden op minimaal hbo-niveau toegenomen, van 76 procent naar 82 procent. Het aandeel dat werkzaam is in het 'kerndomein' groeide eveneens: van 65 procent naar 69 procent. Vergeleken met hbo-breed liggen de percentages binnen de hbo-sector Kunst dus iets lager. Wel is de doorstroom naar werk op minimaal hbo-niveau onder afgestudeerden van de kunstenopleidingen relatief groot (Figuur 2.5). Ook binnen de hbo-sectoren Agro \& Food en Sociale Studies is er veel doorstroom geweest naar banen op minimaal hbo-niveau. In de sectoren waar de aansluiting tussen opleiding en werk in 2010-2011 vaak al goed was, zoals Onderwijs, Bètatechniek en Gezondheidszorg, is er in 2015 weinig veranderd.

Figuur 2.6 toont een specificatie van de aansluiting tussen opleiding en werk voor de verschillende subsectoren van het kunstonderwijs. In alle subsectoren zien we een toename van het aandeel werkenden in het 'kerndomein' en in bijna alle subsectoren (uitgezonderd Creatieve Industrie Techniek) zien we ook een forse toename in het aandeel werkenden op minimaal hbo-niveau. In 2015 waren afgestudeerden uit de subsector Theater het vaakst werkzaam in het 'kerndomein' (73\%), terwijl afgestudeerden uit de subsector Muziek veruit het vaakst een baan op hbo-niveau of hoger hadden (94\%). Wel dienen we voorzichtig te zijn met de interpretatie van deze bevindingen gezien de kleine aantallen respondenten per subsector. 
FIGUUR 2.5 Is functie minimaal op hbo-niveau en in eigen richting, in 2010-2011 en 2015, naar hbosector, voltijd $(n=2677)$

Minimaal hbo-niveau, eigen/verwante richting

Onder hbo-niveau, eigen/verwante richting

Minimaal hbo-niveau, geen/andere richting

Onder hbo-niveau, geen/andere richting W Werkloos

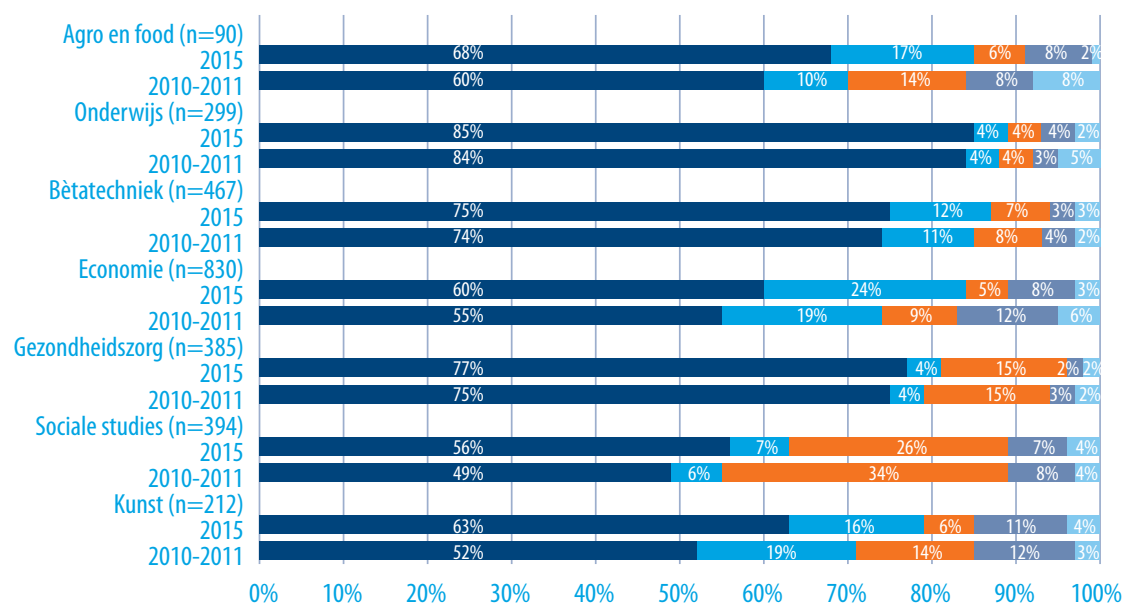

NB: Alleen respondenten die in 2010 c.q. 2011 en in 2015 tot beroepsbevolking behoorden

FIGUUR 2.6 Is functie minimaal op hbo-niveau en in eigen richting, in 2010-2011 en 2015, naar subsector, voltijd $(n=212)$

Minimaal hbo-niveau, eigen/verwante richting Minimaal hbo-niveau, geen/andere richting

Onder hbo-niveau, eigen/verwante richting Onder hbo-niveau, geen/andere richting Werkloos

Beeldende kunst $(n=102)$

2015

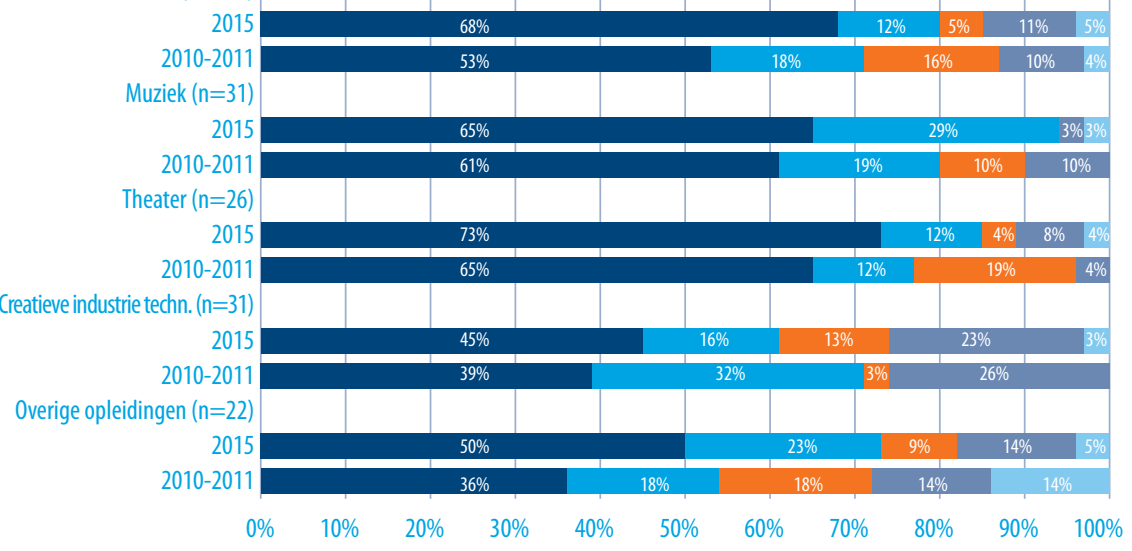

NB: Alleen respondenten die in 2010 c.q. 2011 en in 2015 tot beroepsbevolking behoorden 
In Figuur 2.7 zien we in hoeverre de banen van alumni vijf/zes jaar na afstuderen (2015) aansluiten op hun opleiding, afgezet tegen de situatie één jaar na afstuderen $(2010 / 2011)^{13}$. Er blijkt sprake van een behoorlijke samenhang tussen de uitgangspositie één jaar na afstuderen en de positie vijf/zes jaar na afstuderen. Zo hebben alumni die één jaar na afstuderen een baan in het 'kerndomein' hadden een zeer grote kans (79\%) om dat in 2015 nog steeds te hebben. Ter vergelijking: van de alumni die één jaar na afstuderen een baan onder hbo-niveau hadden én buiten de eigen opleidingsrichting, heeft slechts een kwart in 2015 een baan in het 'kerndomein'.

De behoorlijke mate van samenhang tussen de positie van afgestudeerde kunstenaars in 2010/2011 en 2015 kan op meerdere manieren verklaard worden. Een eerste verklaring ligt in de individuele eigenschappen van afgestudeerden. De eigenschappen die een afgestudeerde in 2010/2011 meer/minder geschikt maakten voor een bepaalde functie, zullen in 2015 deels nog steeds de eigenschappen zijn die iemand meer of minder geschikt maken. Een heel andere verklaring kan zijn dat men door het opdoen van ervaring in een specifiek type werk minder 'uitwijkmogelijkheden' naar andere functies heeft (die mogelijk beter 'matchen' met de vooropleiding). Het spectrum aan potentiële banen is kort na afstuderen doorgaans breder dan wanneer men al een aantal jaar in een bepaalde functie heeft gewerkt (Theeuwes, 2008 ${ }^{14}$ ).

Hoewel er dus zeker sprake is van bepaalde samenhang tussen de situatie in 2010/2011 en de situatie in 2015 , is een 'trage' start op de arbeidsmarkt zeker geen determinerend 'keurslijf'. We zien immers volop veranderingen in de situatie van individuen. Zo heeft meer dan de helft van degenen die aanvankelijk een baan ónder hbo-niveau hadden in 2015 alsnog een baan op hbo-niveau of hoger gevonden. Andersom zijn er ook alumni die een goede start hadden gemaakt (d.w.z. één jaar na afstuderen werkzaam waren in het 'kerndomein'), maar die in 2015 in een baan onder hbo-niveau werkzaam waren of die hun baan zijn verloren.

Aan afgestudeerden die in 2010/2011 en 2015 in hun eigen vakgebied werkzaam waren, is gevraagd of het om één van de volgende functies ging: 'beleidsmatig/management/ organisatorisch werker', 'docent' (o.a. regulier onderwijs en muziekschool) of 'scheppend/uitvoerend kunstenaar/vormgever/ontwerper'. Het overgrote merendeel van de afgestudeerden die in hun eigen vakgebied werken, doen dit (onder meer) als scheppend of uitvoerend kunstenaar/vormgever/ontwerper (Figuur 2.8). Tussen 2010/2011 en 2015 is dit aandeel wel iets afgenomen van 81 procent naar 75 procent. Het lijkt er op dat zij vooral verschoven zijn richting beleidsmatige en organisatorische functies of managementfuncties. Deze categorie groeide namelijk van 22 procent naar 30 procent. Verder gaf ongeveer vier tiende (37\%) op beide meetmomenten aan onder meer werkzaam te zijn als docent.

13 Afgestudeerden die één jaar na afstuderen werkloos waren, zijn in deze figuur buiten beschouwing gelaten vanwege te kleine aantallen.

14 Theeuwes, J. (2008). De levensloop vanuit economisch perspectief. In M. Mol, H. Dirven \& R. van der Bie (Red.), Dynamiek in de sociale statistiek (pp. 23-32). Voorburg: CBS. 
FIGUUR 2.7 Is functie in 2015 minimaal op hbo-niveau en in eigen richting, naar situatie in 2010$2011(n=240)$

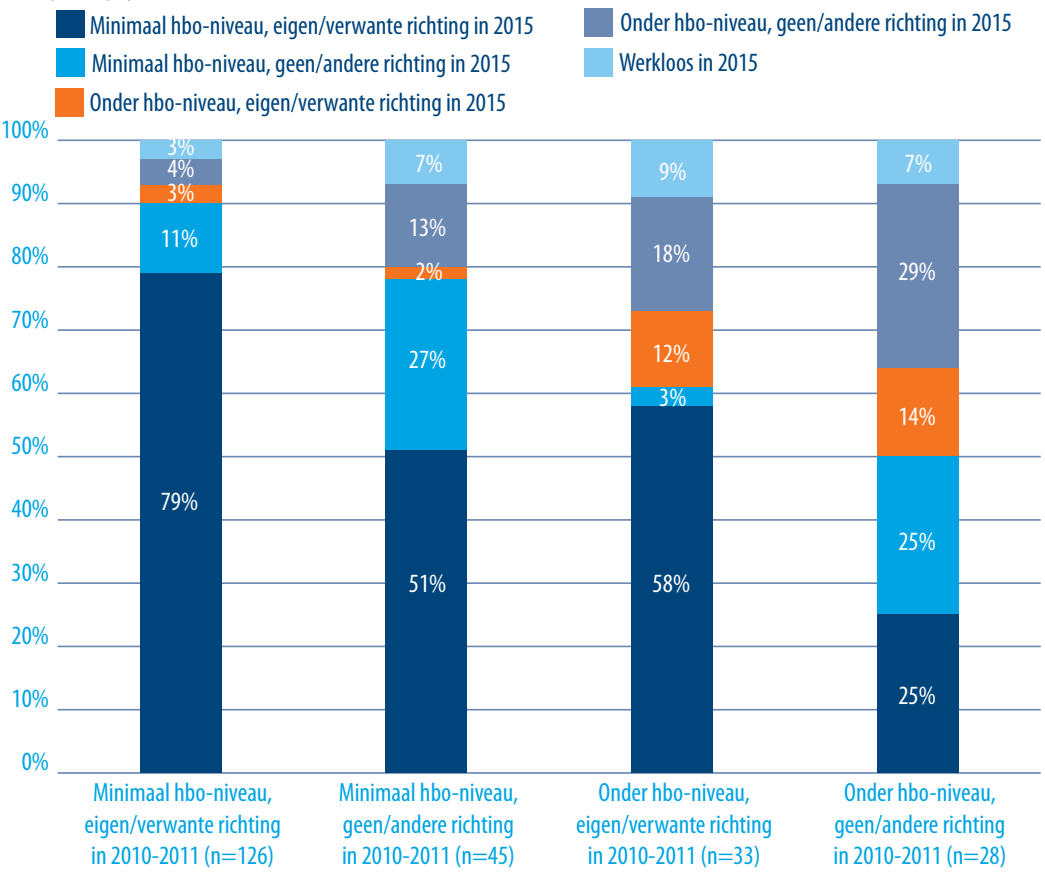

NB: Alleen respondenten die in 2010 c.q. 2011 en in 2015 tot beroepsbevolking behoorden, exclusief werklozen uit 2010/2011 i.v.m. kleine aantallen

FIGUUR 2.8 Indien (deels) werkzaam in vakgebied in 2010-2011 en 2015, in één van de volgende functies, meerdere antwoorden mogelijk $(n=218)$

2010-2011

$90 \%$

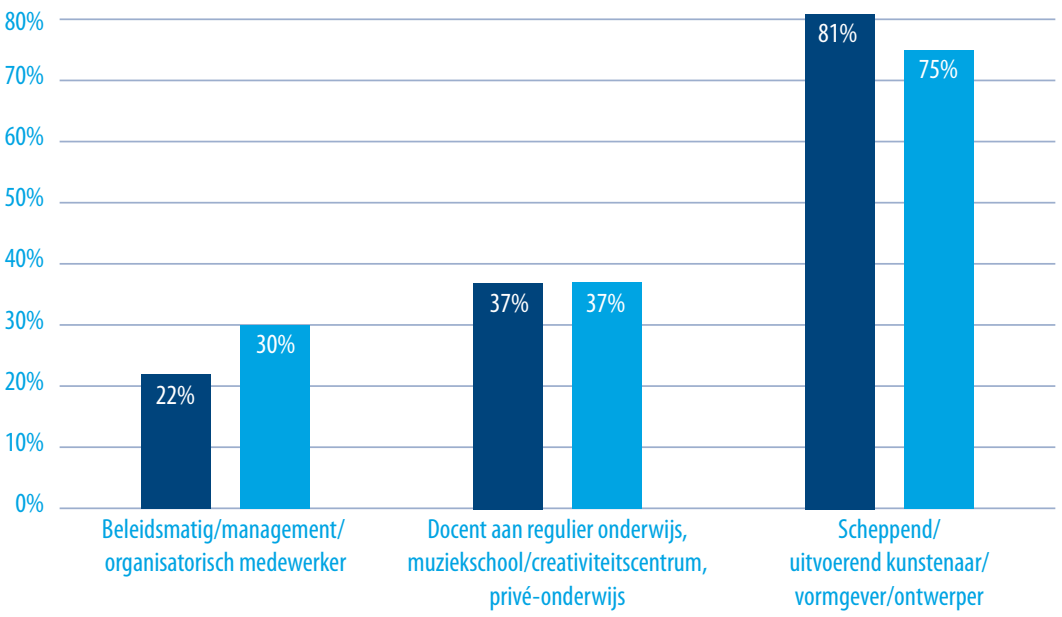

NB: alleen werkzame beroepsbevolking die in 2010-2011 én 2015 (deels) binnen eigen vakgebied werkt 


\subsection{Type dienstverband}

Het aandeel zelfstandigen is tussen 2010/2011 en 2015 sterk afgenomen (Figuur 2.9) ${ }^{15}$. Waar ruim de helft (51\%) van de afgestudeerde kunstenaars één jaar na afstuderen (hoofdzakelijk) als zelfstandige werkte, is dit vijf c.q. zes jaar na afstuderen gedaald tot 39 procent. De afname in het aandeel zelfstandigen is gepaard gegaan met een toename in het aandeel werkenden in loondienst (van 43\% naar 57\%). De afname in het aandeel zelfstandigen heeft mogelijk te maken met het feit dat (sommige) kunstenaars zich als starter moet 'bewijzen', waarna zij na enige jaren ervaring in loondienst aangenomen worden. Een alternatieve verklaring voor de daling ligt in de forse bezuinigingen op kunst en cultuur in de afgelopen jaren, waardoor de voortzetting van eigen initiatieven mogelijk moeilijker is geworden.

Hoewel er diverse verklaringen zijn voor het afnemend aandeel zelfstandigen onder afgestudeerde kunstenaars, staat deze ontwikkeling haaks op het algemene beeld binnen de cultuursector. Zo concludeerde de Commissie Arbeidsmarktverkenning Cultuursector in $\mathbf{2 0 1 6}$ dat "[h] tet aantal zelfstandigen in de culturele sector in de periode 2009 tot en met 2013 sterk [is] gestegen. Met een groei van 20,4 procent is die stijging veel sterker dan in de economie als geheel, waar het aantal zelfstandigen met 9,6 procent is toegenomen." (p.10). Dit lijkt te impliceren dat met name 'oudere', ervaren kunstenaars de stap naar zelfstandigheid hebben gemaakt. Onder de pas afgestudeerde kunstenaars aan het hbo (in 2015: maximaal zes jaar na diplomering) is er immers een forse daling in het aantal zelfstandigen waarneembaar.

Figuur 2.10 toont voor de verschillende hbo-sectoren het aandeel afgestudeerde voltijdstudenten die (voornamelijk) als zelfstandige werkzaam zijn. Het aandeel zelfstandigen is binnen de sector Kunst, ondanks een afname, zowel in 2010-2011 als in 2015 verhoudingsgewijs zeer hoog. Ter vergelijking: in de hbo-sector Agro \& Food, met bovengemiddeld veel zelfstandigen, gaat het respectievelijk om 'slechts' 6 procent en 12 procent.

15 Op basis van de hoofdfunctie van respondenten. In de praktijk is bekend dat er in de culturele sector relatief vaak hybride arbeidsrelaties voorkomen, waarbij een zelfstandige ook werkzaamheden (binnen óf buiten het vakgebied) in loondienst verricht. 


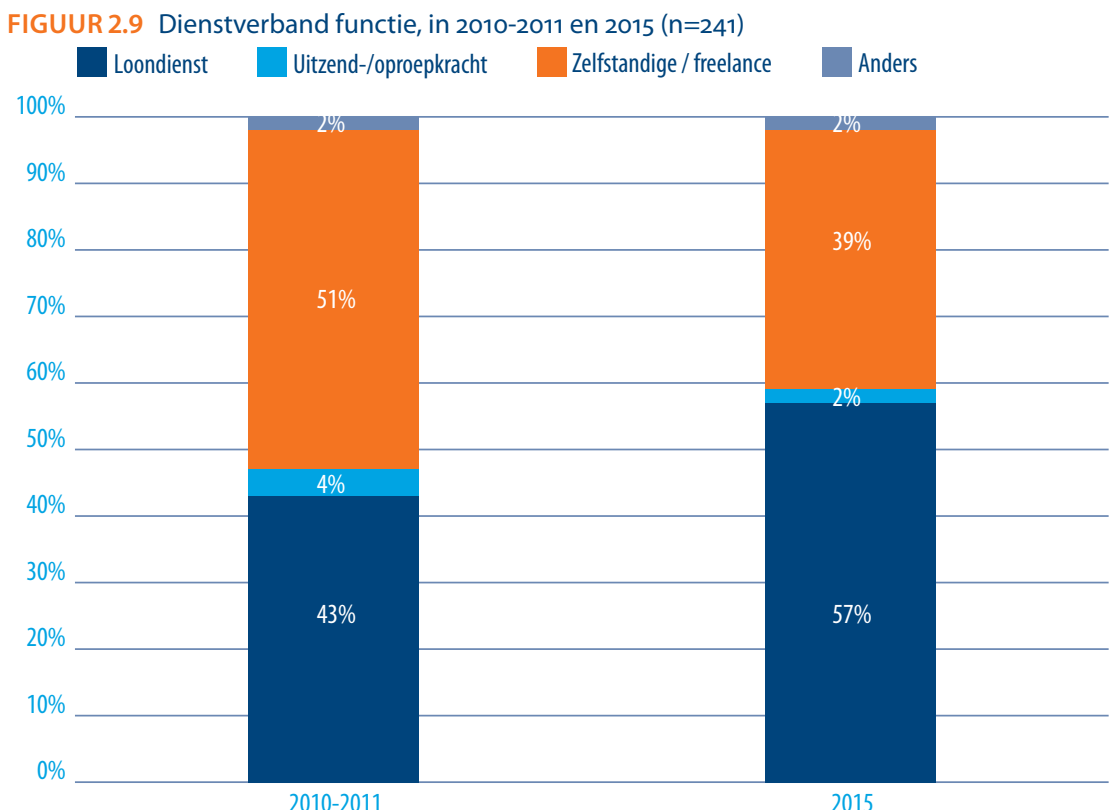

NB: Alleen respondenten die in 2010 c.q. 2011 en in 2015 tot werkzame beroepsbevolking behoorden

FIGUUR 2.10 Percentage zelfstandigen, in 2010-2011 en 2015, naar hbo-sector, voltijd ( $n=2481)$ 2010-2011—2015

$60 \%$

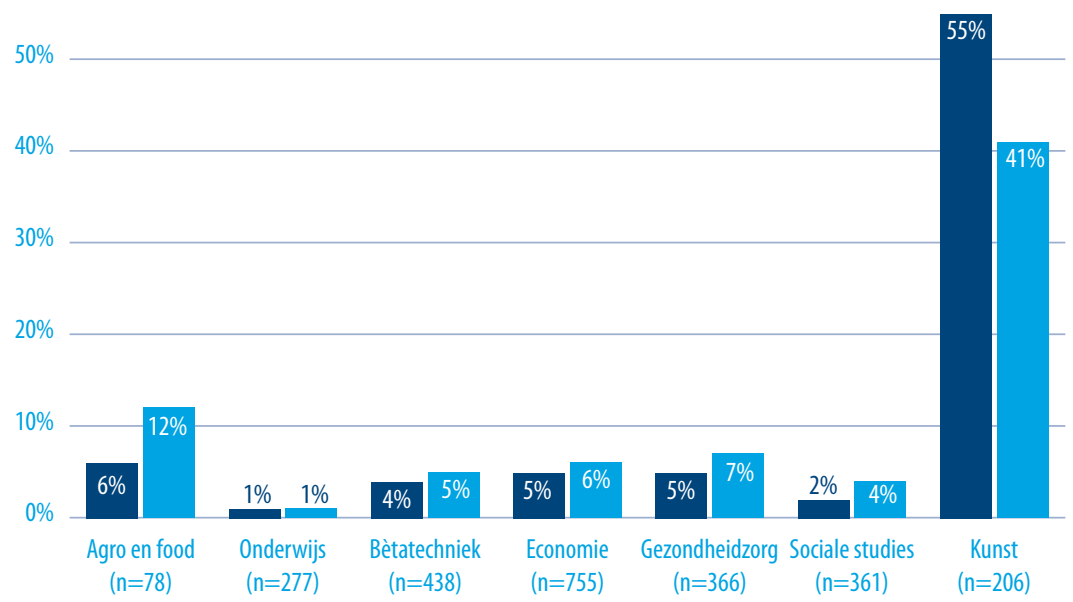

NB: Alleen respondenten die in 2011 en in 2015 tot werkzame beroepsbevolking behoorden. Onder 'zelfstandigen' worden hier ook meewerkende gezinsleden gerekend. Exclusief dienstverband 'anders'. 
In alle subsectoren van het kunstonderwijs is het aandeel zelfstandigen afgenomen (Figuur 2.11). Vooral in de subsector Creatieve Industrie Techniek is de daling zeer groot: waar 58 procent van deze afgestudeerden één jaar na afstuderen als zelfstandige werkte, is dit vijf c.q. zes jaar na afstuderen nog maar 29 procent. Het grootste aandeel zelfstandigen vinden we binnen de subsector Muziek: ondanks de afname in het percentage werkt in 2015 nog steeds meer dan de helft van de afgestudeerden als zelfstandige.

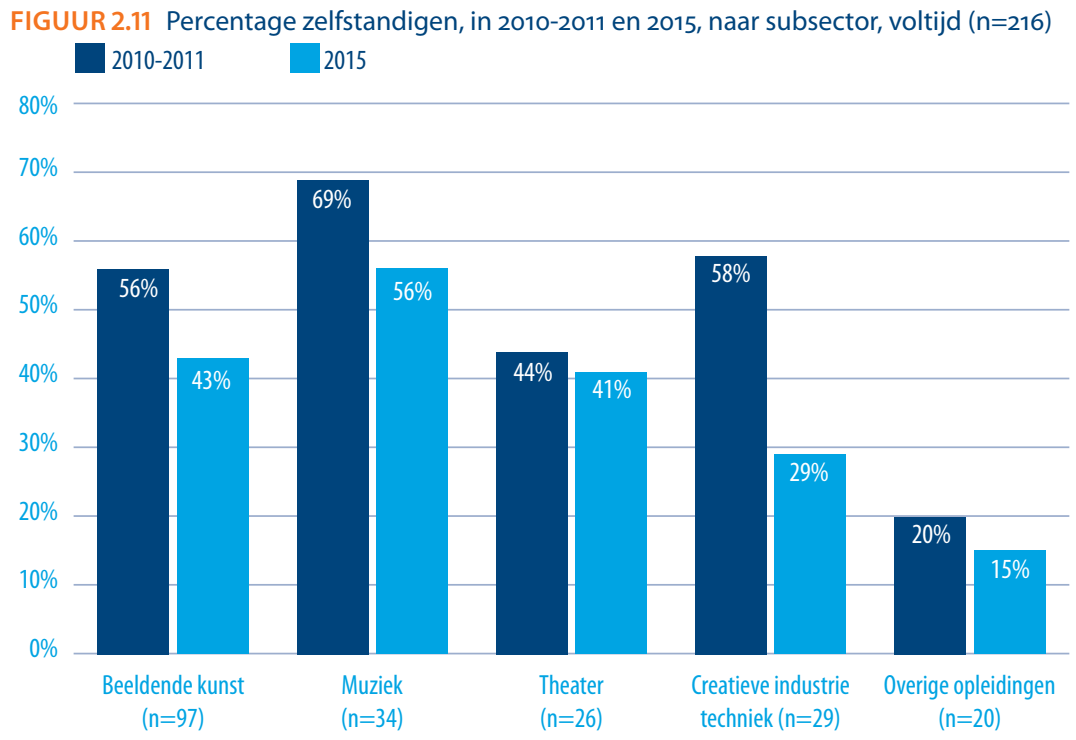

NB: Alleen respondenten die in 2010 c.q. 2011 en in 2015 tot werkzame beroepsbevolking behoorden. Onder 'zelfstandigen' worden hier ook meewerkende gezinsleden gerekend. Exclusief dienstverband 'anders'.

De overgrote meerderheid van de afgestudeerde kunstenaars die in 2010/2011 in loondienst werkten, werkt in 2015 nog steeds in loondienst. Figuur 2.12 toont dat slechts 8 procent van degenen die destijds in loondienst werkzaam waren, in 2015 zelfstandige is geworden. Andersom zijn er (in lijn met de eerdere bevindingen) veel meer'overstappers' geweest van zelfstandige naar loondienst. Tweederde van de zelfstandigen (67\%) uit 2010/2011 werkt in 2015 nog steeds als zelfstandige. 
FIGUUR 2.12 Percentage zelfstandigen in 2015, naar type dienstverband functie in 2010-2011 ( $\mathrm{n=231}$ ) $80 \%$

$70 \%$

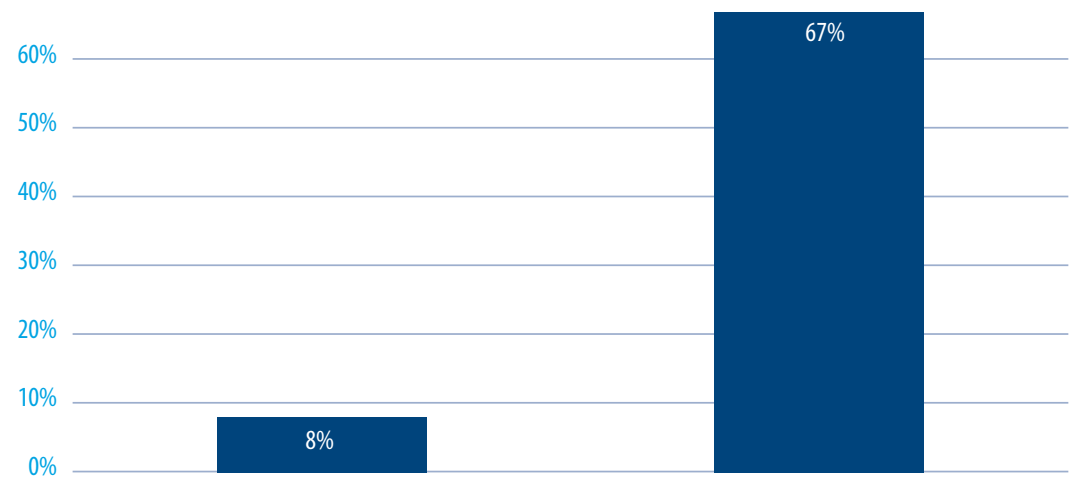

Loondienst in 2010-2011

$(n=110)$

Zelfstandige in 2010-2011

$(n=121)$

NB: alleen respondenten die in 2010/2011 en 2015 tot werkende beroepsbevolking behoren en in loondienst of als zelfstandige werken

FIGUUR 2.13 Bruto uurlonen in euro: 10e, 25e, 50e (mediaan), 75e en 9oe percentiel, in 2010-2011 en $2015(n=196)$
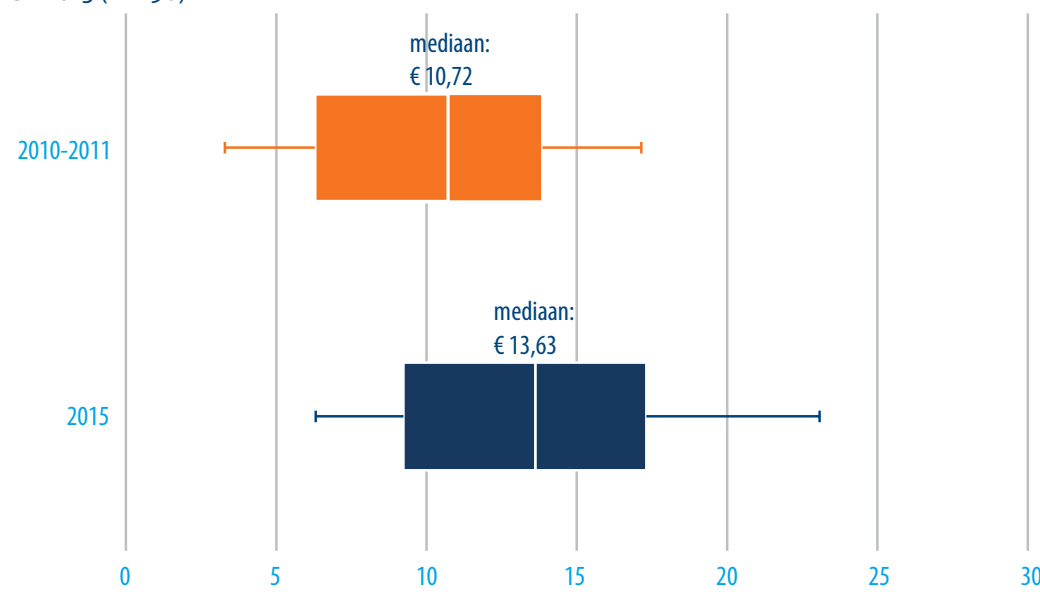

NB: Alleen respondenten die in 2010 c.q. 2011 en in 2015 tot werkzame beroepsbevolking behoorden 


\subsection{Lonen}

De bruto uurlonen van afgestudeerden van de kunstenopleidingen zijn tussen 2010/2011 en 2015 fors toegenomen (Figuur 2.13). Waar het mediaan uurloon in 2010/2011 nog $€ 10,72$ betrof, is het in 2015 gegroeid tot $€ 13,63$ (na inflatiecorrectie). De lonen zijn dus toegenomen met 27 procent. Verder toont de figuur een flinke spreiding in de lonen, zo is het uurloon voor het $25^{\mathrm{e}}$ percentiel in 2015 minder dan €10,- terwijl het 75e percentiel ongeveer $€ 17$,- per uur betreft.

De lonen onder afgestudeerde deeltijdstudenten liggen zowel één als vijf/zes jaar na afstuderen hoger dan onder voltijdstudenten (respectievelijk $26 \%$ en $21 \%$ hoger). Dit is echter niet verwonderlijk, aangezien deeltijdstudenten vaak een baan combineren met hun studie. Zij hebben dus al vaak ervaring op de arbeidsmarkt opgedaan en zijn bovendien gemiddeld ouder dan voltijdstudenten. Wel is de loongroei onder voltijdstudenten sterker dan onder deeltijdstudenten (respectievelijk $27 \%$ en $22 \%$ toename), waardoor het loonverschil kleiner is geworden.

In alle hbo-sectoren zijn de lonen tussen 2010/2011 en 2015 gegroeid (Figuur 2.14). De lonen van afgestudeerde uit de kunstenopleidingen liggen echter fors lager dan elders, zowel één jaar als vijf/zes jaar na diplomering. Wel is de relatieve loongroei binnen de sector Kunst, tezamen met de sectoren Bètatechniek en Economie, het sterkst geweest. De lonen zijn verhoudingsgewijs het minst gegroeid in de sectoren Onderwijs en Sociale Studies (tussen 9\% en 10\%). Hbo-breed zijn de lonen voor voltijdstudenten toegenomen met 22 procent. Absoluut liggen de lonen in 2015 het hoogst onder afgestudeerden uit de sector Bètatechniek.

Binnen de kunstenopleidingen zijn de lonen zowel in 2010/2011 als in 2015 het laagst voor de subsector Beeldende Kunst (Figuur 2.15). De hoogste lonen vinden we in 2010/2011 bij de subsector Creatieve Industrie Techniek. In 2015 liggen de lonen het hoogst bij zowel Creatieve Industrie Techniek als bij Theater. In alle subsectoren is er sprake is van een forse loongroei, maar de subsector Theater laat de sterkste loongroei zien over de twee meetmomenten. Wel dient wederom sterk rekening gehouden te worden met de relatief kleine aantallen respondenten. 
FIGUUR 2.14 Mediaan bruto uurloon, in 2010-2011 en 2015, naar hbo-sector, voltijd ( $\mathrm{n}=677$ ) 2010-2011 2015

20

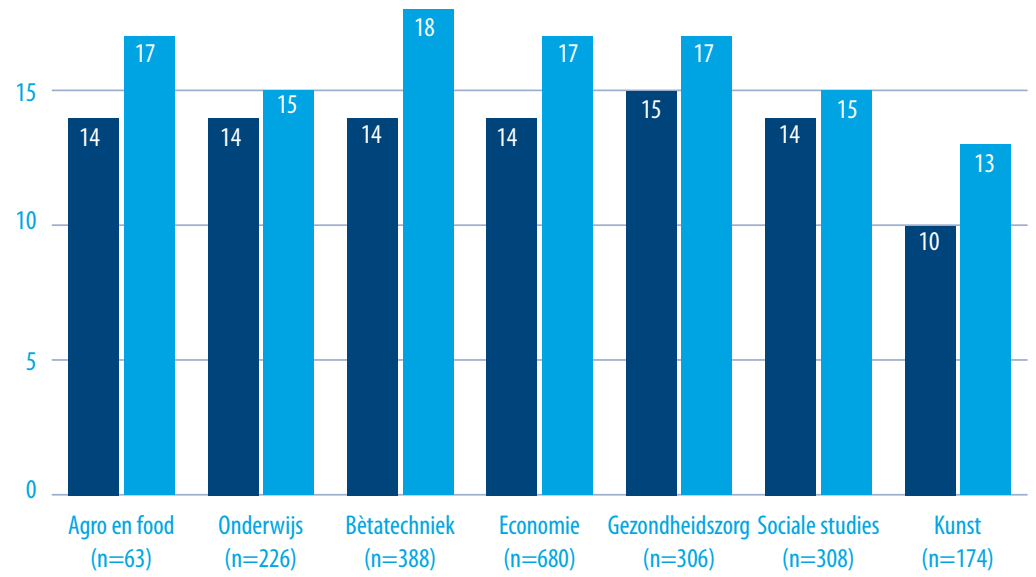

NB: Alleen respondenten die in 2011 en in 2015 tot werkzame beroepsbevolking behoorden

FIGUUR 2.15 Mediaan bruto uurloon, in 2010-2011 en 2015, naar subsector, voltijd ( $\mathrm{n=132)}$

2010-2011 2015

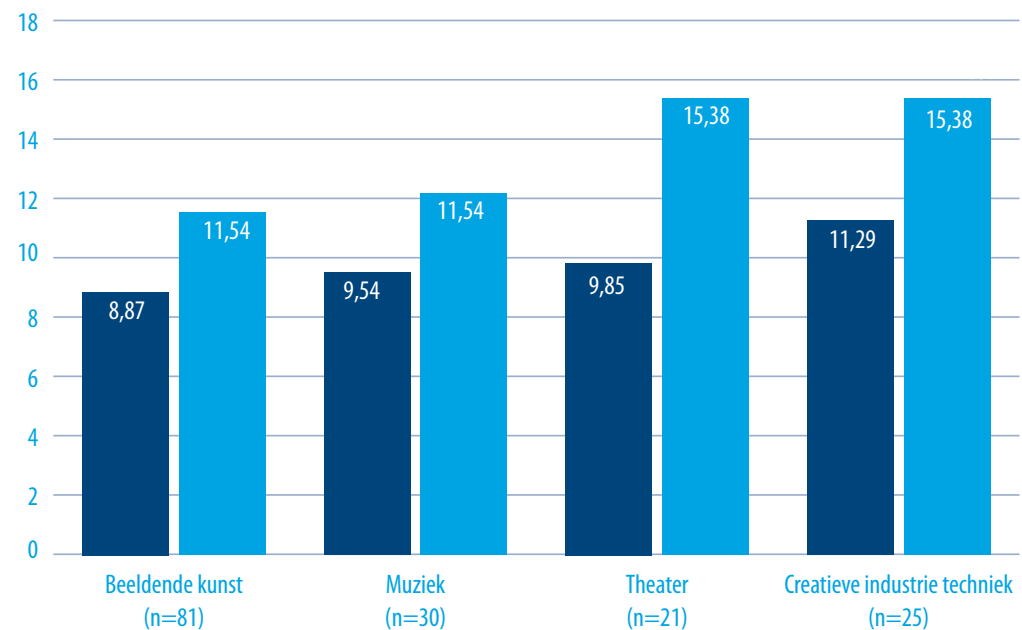

NB: Alleen respondenten die in 2010 c.q. 2011 en in 2015 tot werkzame beroepsbevolking behoorden. Exclusief 'Overige opleidingen' vanwege te kleine aantallen. 


\subsection{Carrièremogelijkheden huidige functie (2015)}

Figuur 2.16 laat zien hoe werkende afgestudeerden in 2015 (dus vijf/zes jaar na diplomering) hun carrièremogelijkheden beoordelen. We zien dat bijna de helft van de voltijdstudenten (48\%) veel carrièremogelijkheden in hun huidige baan ervaart. Slechts een kwart ervaart weinig mogelijkheden. Onder deeltijdstudenten zien we juist een omgekeerd patroon: slechts een derde (33\%) ervaart goede carrièremogelijkheden tegenover 44 procent met matige mogelijkheden. In totaal (voltijd en deeltijd gezamenlijk) ervaart 47 procent van de kunstenaars goede carrièremogelijkheden in hun baan.

Hoewel deze verschillen erg groot zijn is het op zich niet verwonderlijk dat de gepercipieerde carrièremogelijkheden verschillen tussen deze groepen. Deeltijdstudenten zijn meestal al wat ouder en combineren een baan vaak met een opleiding. Daarentegen hebben voltijdstudenten vaak nog geen tot nauwelijks arbeidsmarktervaring. Juist in de eerste paar jaar zijn de loopbaanmogelijkheden vaak het grootst. Zo kennen veel werkgevers 'startersfuncties' waarin de nieuwkomer aan de omgeving en het type werk kan wennen, waarna men na enkele jaren ervaring kan doorstromen naar een meer zelfstandige, hogere functie. Verdere doorstroom vanuit een hogere functie kan dan moeilijker zijn.

FIGUUR 2.16 Biedt uw functie goede carrièremogelijkheden, in $2015(\mathrm{n}=256)$

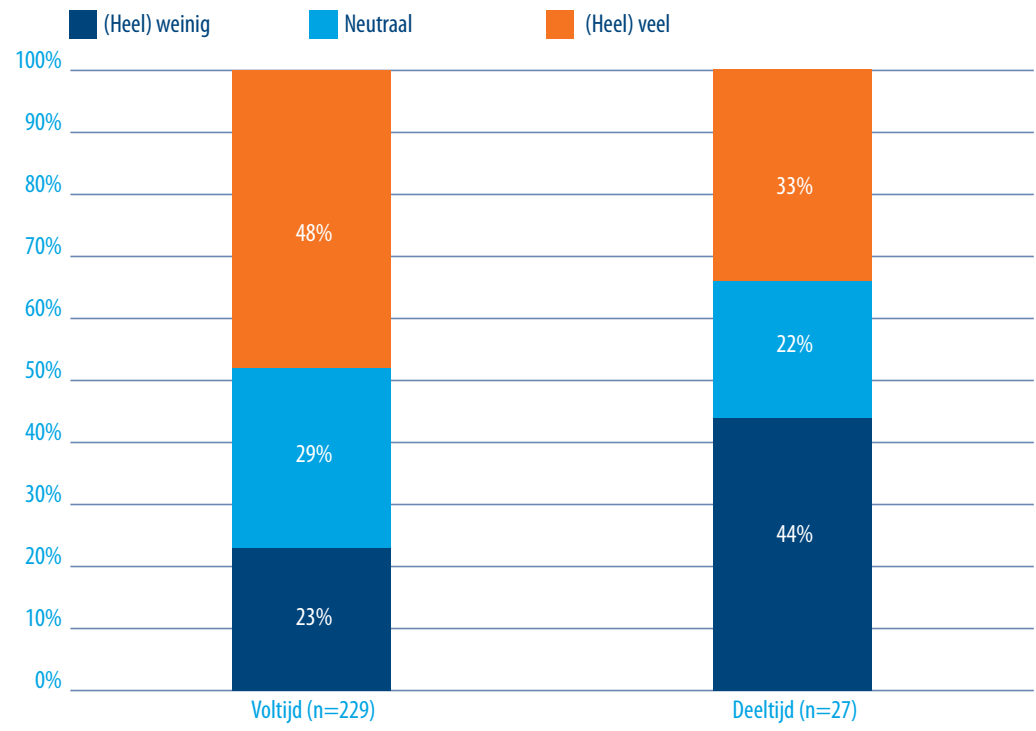

NB: Alleen respondenten die in 2015 tot werkzame beroepsbevolking behoorden.

Ten opzichte van de andere hbo-sectoren ervaren de afgestudeerden uit de sector Kunst in 2015 relatief vaak goede carrièremogelijkheden (Figuur 2.17). Afgestudeerden uit de Bètatechniek (55\%) en de Economie (54\%) zijn het meest positief over de loopbaanmo- 
gelijkheden, gevolgd door alumni van kunstenopleidingen (48\%). Afgestudeerden uit de sectoren Onderwijs en Sociale Studies ervaren veel minder vaak goede carrièremogelijkheden (respectievelijk $26 \%$ en $28 \%$ ). Het hbo-brede gemiddelde ligt voor voltijdstudenten op 43 procent.

FIGUUR 2.17 Percentage dat (heel) veel carrièremogelijkheden ervaart in huidige functie, in 2015, naar hbo-sector, voltijd $(n=2185)$

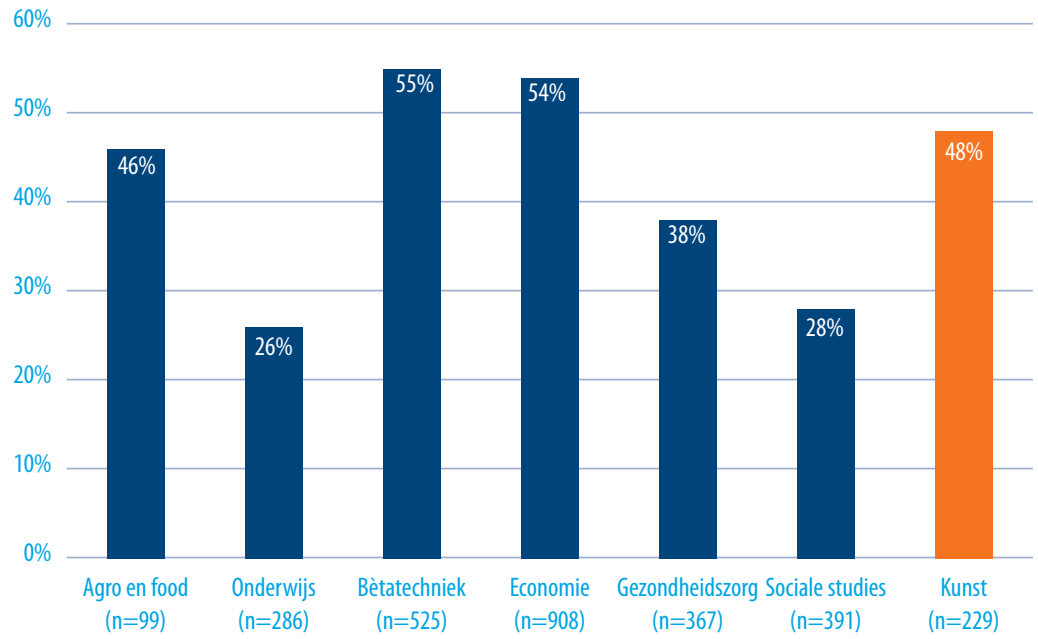

NB: Alleen respondenten die in 2015 tot werkzame beroepsbevolking behoorden.

FIGUUR 2.18 Biedt uw functie goede carrièremogelijkheden, in 2015, naar subsector, voltijd ( $n=229$ )

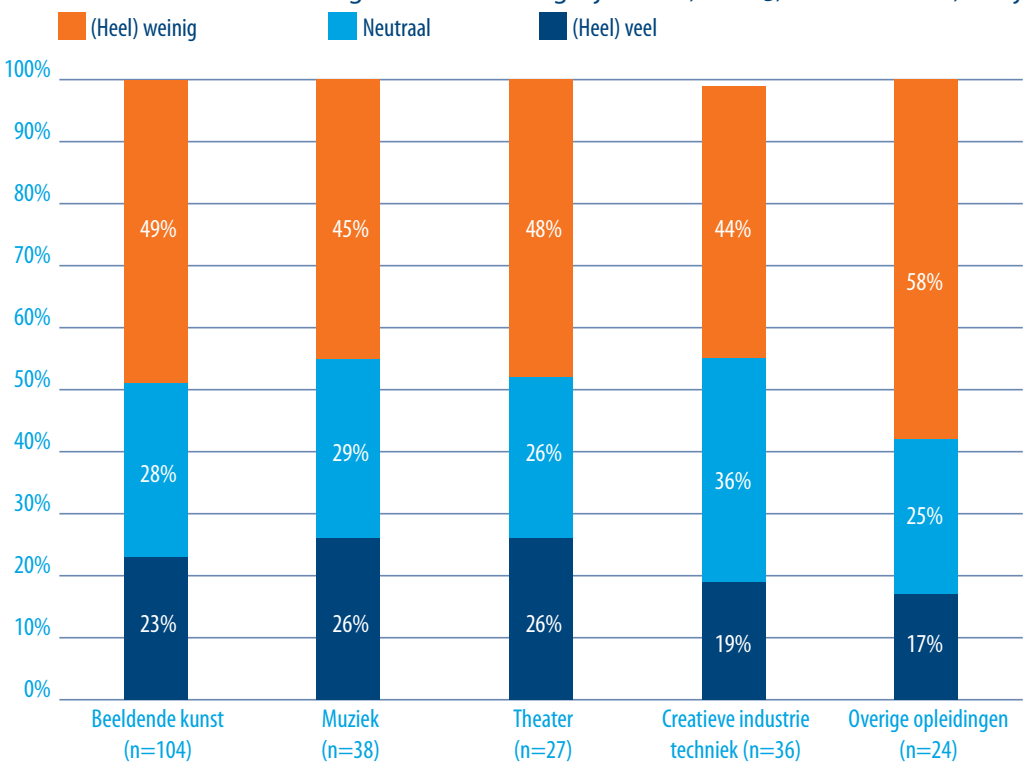

NB: Alleen respondenten die in 2015 tot werkzame beroepsbevolking behoorden. 
Een nadere uiteenzetting van de kunstenopleidingen naar subsector, laat zien dat er in alle subsectoren relatief veel loopbaanmogelijkheden worden ervaren (Figuur 2.18). In alle subsectoren zijn minstens vier op de tien alumni van mening dat hun huidige baan hen goede carrièremogelijkheden biedt. De carrièremogelijkheden worden het hoogst ingeschat binnen de categorie Overige Opleidingen, maar gezien de diversiteit van opleidingen is deze bevinding moeilijk te interpreteren.

\subsection{Tevredenheid huidige functie (2015)}

Bijna zeven op de tien afgestudeerden uit de kunstsector zijn in 2015 tevreden over de huidige baan (geen verschillen tussen voltijd- en deeltijdstudenten). De baantevredenheid onder afgestudeerde kunstenaars blijkt vijf/zes jaar na afstuderen het hoogst van alle hbo-sectoren (Figuur 2.19). Naast de sector Kunst (68\% tevreden) ligt de baantevredenheid eveneens relatief hoog in de sectoren Bètatechniek en Gezondheidszorg (beide $66 \%)$. De baantevredenheid is het laagst onder alumni uit de Sociale Studies (54\%). Hbo-breed is 63 procent van de voltijdstudenten tevreden.

FIGUUR 2.19 Percentage dat (zeer) tevreden is met huidige functie, in 2015, naar hbo-sector, voltijd $(n=2228)$

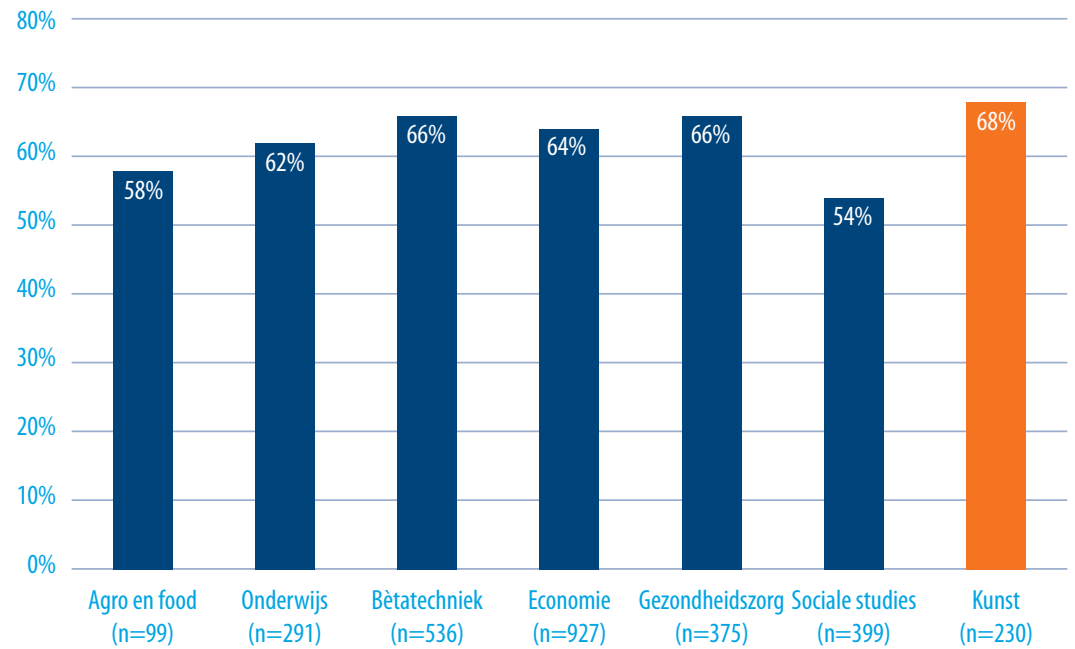

NB: Alleen respondenten die in 2015 tot werkzame beroepsbevolking behoorden.

Binnen alle subsectoren van de kunstenopleidingen is er sprake van een hoge mate van baantevredenheid (Figuur 2.20). Bovendien is er vrij weinig variatie in de baantevredenheid tussen de subsectoren. Wel valt op dat vrijwel geen van de alumni uit de subsector Muziek ontevreden is ( $5 \%$ ontevreden). Ook de categorie Overige Opleidingen valt op met een relatief hoge tevredenheid ( $79 \%$ tevreden), maar wederom is dit moeilijk te duiden gezien de variatie aan onderliggende opleidingen. 
FIGUUR 2.20 Hoe tevreden bent u met uw huidige functie, in 2015, naar subsector, voltijd ( $n=230$ )

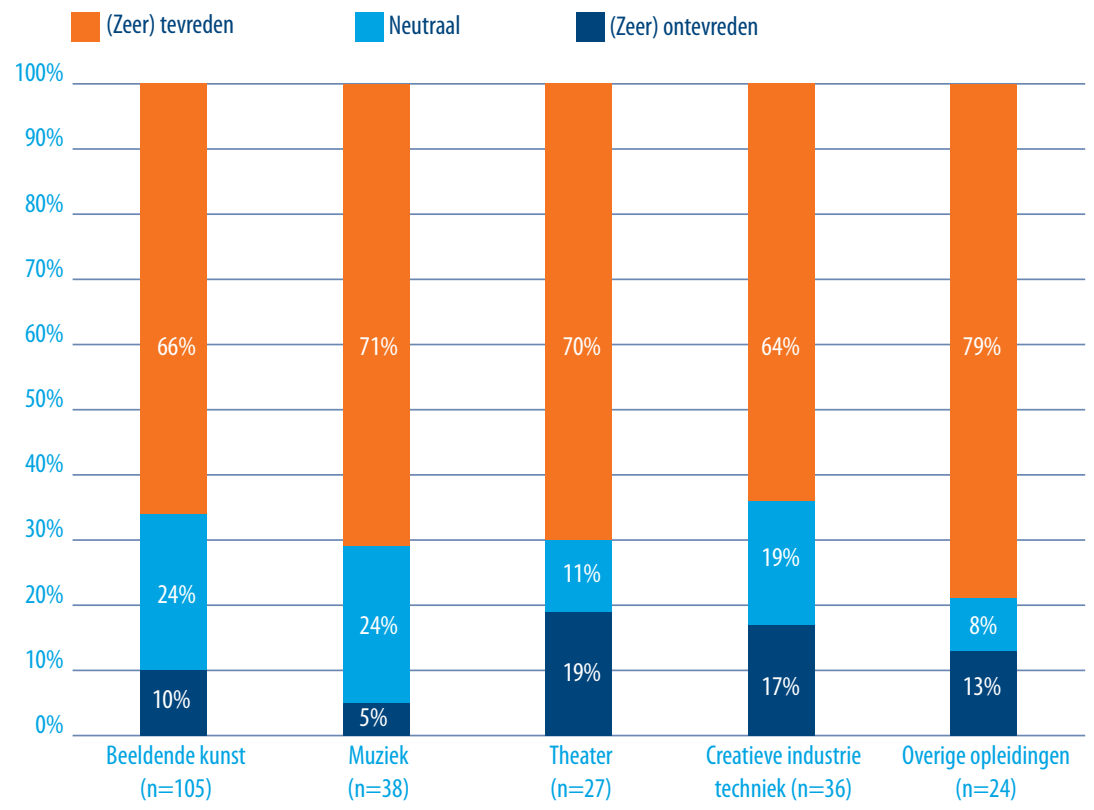

NB: Alleen respondenten die in 2015 tot werkzame beroepsbevolking behoorden.

\subsection{Werkdruk (2015)}

In 2015 zijn afgestudeerden bevraagd in welke mate zij werkdruk ${ }^{16}$ ervaren in hun huidige baan. Figuur 2.21 toont per hbo-sector het aandeel afgestudeerde voltijdstudenten dat relatief veel werkdruk ervaart (dat wil zeggen een gemiddelde schaalscore van 3,5 of hoger). Samen met alumni uit het Onderwijs (36\%) ervaren afgestudeerden uit de kunstenopleidingen relatief vaak (34\%) een hoge werkdruk. Hbo-breed gaat het om ongeveer een kwart. Alumni uit de Sociale Studies geven het minst vaak aan een hoge werkdruk te ervaren (15\%). De verschillen tussen de sectoren zijn daarmee groot. Uit onderzoek (Smulders \& Houtman, 2004 ${ }^{17}$ ) is bekend dat werkdruk vooral samenhangt met complex, onvoorspelbaar, zwaar en repeterend, emotioneel, en leidinggevend werk. Mogelijk hebben afgestudeerden uit de sectoren Kunst en Onderwijs in hun werk vaker met (een aantal van) deze aspecten te maken. Wel dienen we er rekening mee te houden dat de ervaring van werkdruk zeer persoonlijk is. Daarbij kán hoge werkdruk

16 Deze schaal (Cronbachs alpha $=0,82$ ) bestaat uit 8 items, waarvan minimaal 7 beantwoord moeten zijn: a) 'Er is vaak grote tijdsdruk door een hoge werkbelasting'; b) 'Het gebeurt vaak dat ik al bij het wakker worden aan werkproblemen denk'; c) 'Als ik thuis kom, kan ik mijn werk heel makkelijk van me afzetten' (t.b.v. analyse omgekeerd gecodeerd); d) 'Degenen, die mij het dierbaarst zijn, zeggen dat ik me te veel voor mijn werk opoffer'; e) 'Het werk laat me zelden los, zelfs's avonds spookt het nog door mijn hoofd'; f) 'Als ik iets uitstel dat ik eigenlijk vandaag had moeten doen, kan ik's nachts niet slapen'; g) 'Tijdens mijn werk word ik vaak gestoord en onderbroken'.

17 Smulders, P., \& Houtman, I. (2004). Oorzaken van werkdruk: een onderbelicht thema. Tijdschrift voor Arbeidsvraagstukken, 20(1), 90-106. 
een risicofactor zijn, maar hoeft een hoge werkdruk niet voor iedereen per definitie als problematisch te worden ervaren.

FIGUUR 2.21 Percentage met schaalscore 'werkdruk' van 3,5 of hoger, in 2015, naar hbo-sector, voltijd $(n=2834)$

$40 \%$

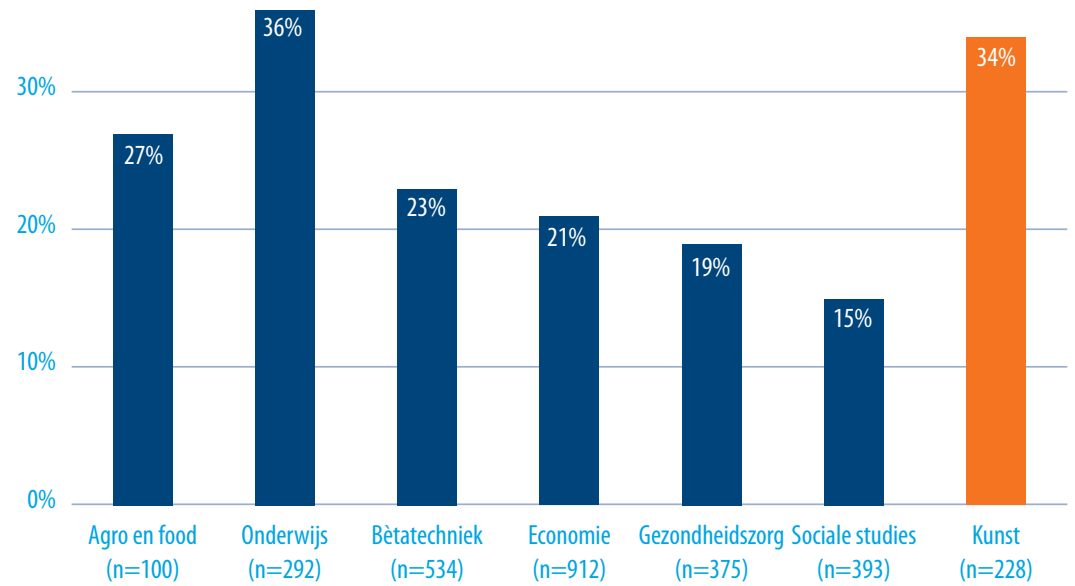

NB: Alleen respondenten die in 2015 tot werkzame beroepsbevolking behoorden.

FIGUUR 2.22 Percentage met schaalscore 'werkdruk' van 3,5 of hoger, in 2015, naar subsector, voltijd $(n=228)$

$60 \%$

$50 \%$

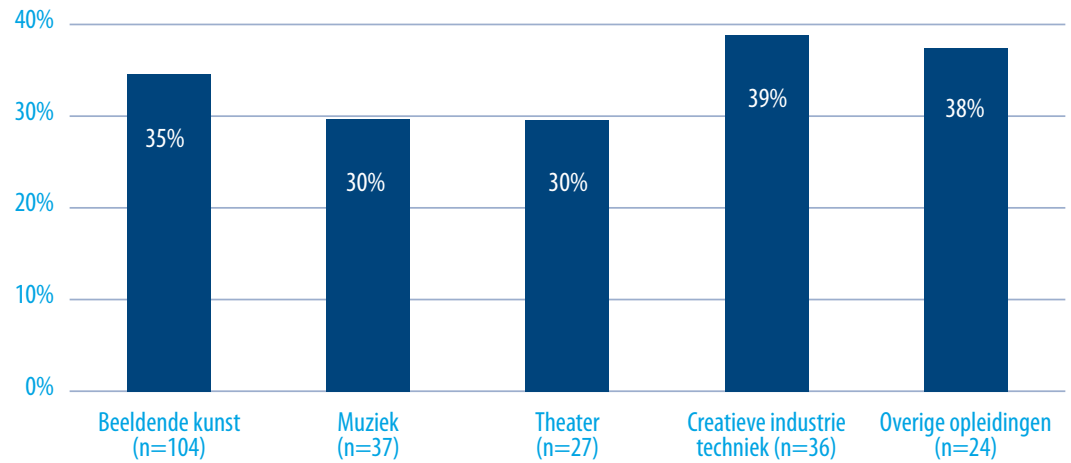

NB: Alleen respondenten die in 2015 tot werkzame beroepsbevolking behoorden. 
Alumni uit de Theater-opleidingen geven van de afgestudeerde kunstenaars het vaakst aan hoge werkdruk te ervaren. Bijna vier op de tien (39\%) uit deze subsector ervaart in 2015 een hoge werkdruk, zo blijkt uit Figuur 2.22. De subsector Overige Opleidingen toont wederom een opvallend, maar moeilijk te interpreteren beeld (hoog percentage alumni met grote werkdruk). Ook in de overige subsectoren ervaren de alumni een hogere werkdruk dan hbo-gemiddeld. 


\section{TERUGBLIK OP DE OPLEIDING}

\subsection{Studietevredenheid (2015)}

Twee derde van de afgestudeerde kunstenaars geeft vijf/zes jaar na afstuderen aan (zeer) tevreden te zijn over de opleiding. Dit geldt zowel voor voormalige voltijd- als deeltijdstudenten. De studietevredenheid binnen de kunstenopleidingen ligt daarmee op gelijke hoogte met het hbo-brede gemiddelde (65\%). Figuur 3.1 laat zien dat de studietevredenheid tussen de verschillende hbo-sectoren redelijk vergelijkbaar is, alleen onder afgestudeerden uit het Onderwijs is de tevredenheid relatief laag (58\%).

FIGUUR 3.1 Percentage dat (zeer) tevreden is over studie in algemeen, in 2015, naar hbo-sector, voltijd $(n=2999)$

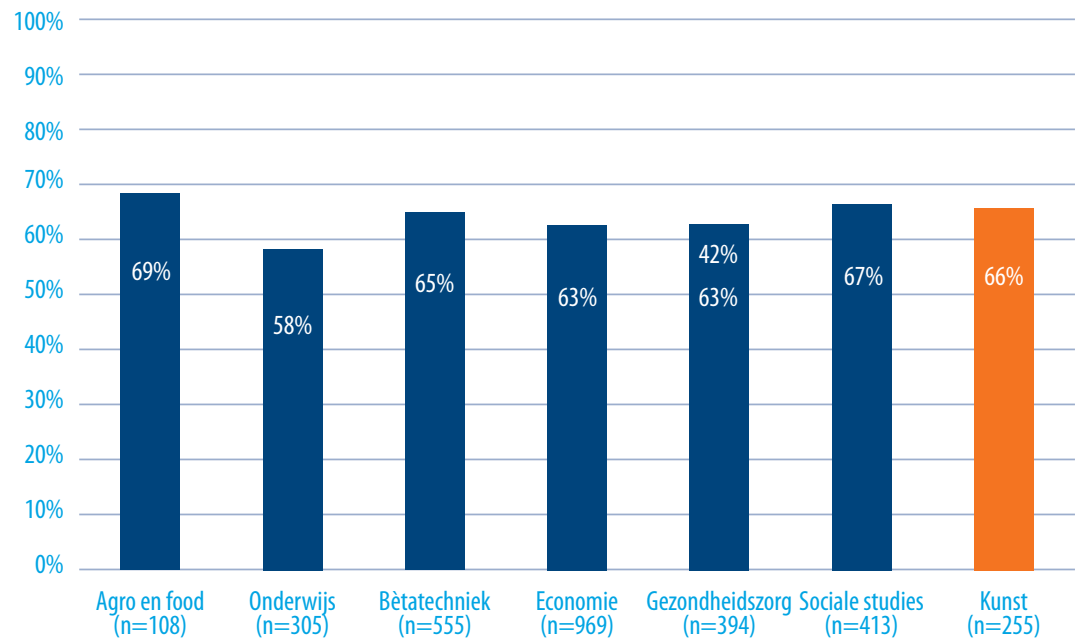

De studietevredenheid binnen de kunstenopleidingen verschilt enigszins naar subsector (Figuur 3.2). Het percentage tevredenen ligt onder alumni van de Theater-opleidingen wat lager dan gemiddeld in de kunstensector (57\% tegen 66\%). We zien echter dat dit niet zozeer te wijten is aan een groter aandeel 'ontevredenen' binnen deze groep, maar vooral aan een grotere groep alumni die 'neutraal' is over de studie. Het aandeel afgestudeerde kunstenaars dat ontevreden is, blijkt binnen alle subsectoren erg laag (tussen 
$8 \%$ en $14 \%$ ). De brede subsector Overige Opleidingen valt ook in deze figuur weer op met een hoge tevredenheid.

FIGUUR 3.2 Hoe tevreden bent u over studie in algemeen, in 2015, naar subsector, voltijd ( $\mathrm{n}=\mathbf{2 5 5}$ )

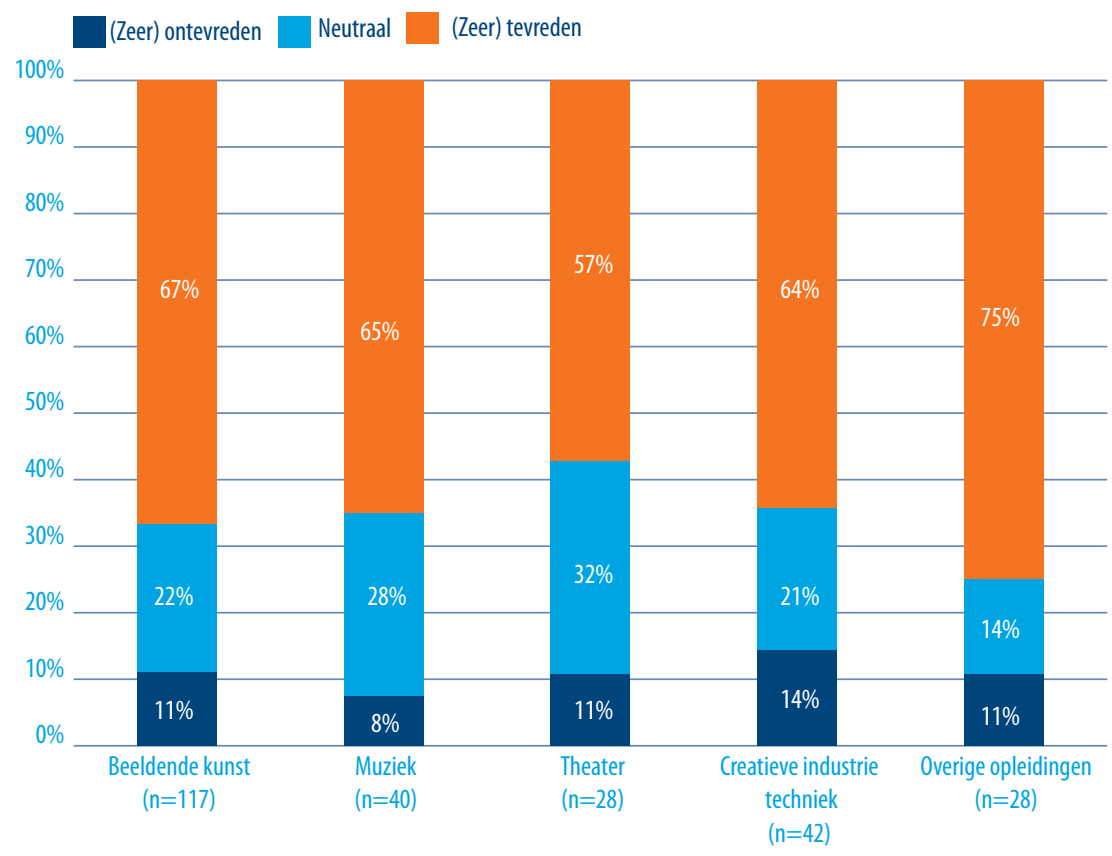

\subsection{Voorbereiding studie op loopbaan (2015)}

Hoewel alumni uit de kunsten overwegend positief zijn over de studie in het algemeen, is men aanzienlijk kritischer over de voorbereiding van de opleiding op de loopbaan. Onder voltijdstudenten is hier slechts 24 procent tevreden over en 44 procent is hier zelfs ontevreden over (Figuur 3.3). Onder deeltijdstudenten is 29 procent hier tevreden over en 34 procent ontevreden. Mogelijk heeft een deel van de deeltijdstudenten een opleiding gevolgd in het kader van een mobiliteitstraject binnen hun werkgever, waardoor de gevolgde studie directer aansluit op de (voorbereiding op de verdere) loopbaan.

De relatief lage tevredenheid over de voorbereiding van de studie op de loopbaan, wordt nog eens onderschreven door Figuur 3.4. We zien dat voltijdstudenten uit de andere hbo-sectoren hier veel tevredener over zijn. Hbo-breed geeft 42 procent van de afgestudeerden in 2015 aan tevreden te zijn over de studie ter voorbereiding op de verdere loopbaan. Er zijn hier relatief weinig sectorale verschillen waarneembaar, met uitzondering van de sector Kunst waar de tevredenheid laag is. Wellicht ervaren kunstenstudenten in mindere mate een voorbereiding op de loopbaan, omdat zij vooral voor hun studie kiezen om in hun passie te investeren en deze uit te kunnen oefenen. De geper- 
cipieerde connectie met de arbeidsmarkt is dan wellicht minder sterk. Desalniettemin is de lage tevredenheid binnen de kunsten wel een aandachtspunt voor de sector.

FIGUUR 3.3 Tevredenheid over studie ter voorbereiding op (verdere) loopbaan, naar voltijd, deeltijd, in $2015(n=292)$

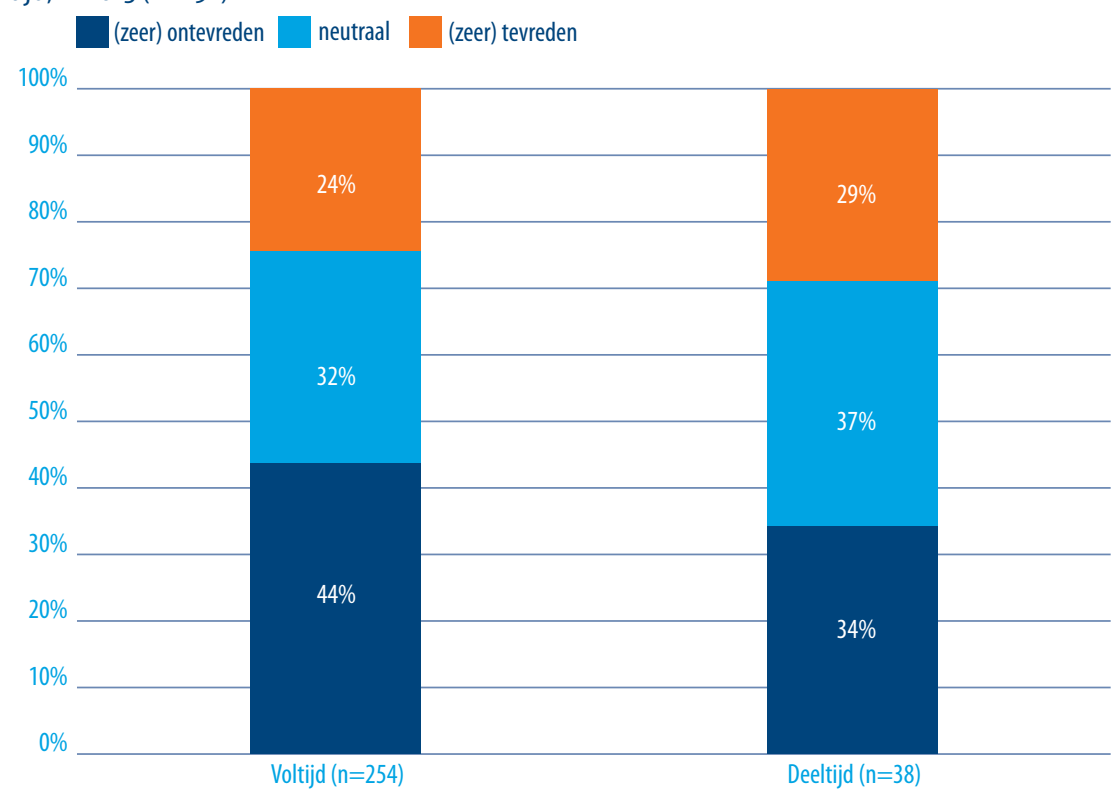

FIGUUR 3.4 Percentage dat (zeer) tevreden is over studie ter voorbereiding op (verdere) loopbaan, in 2015, naar hbo-sector, voltijd ( $\mathrm{n}=2993$ )

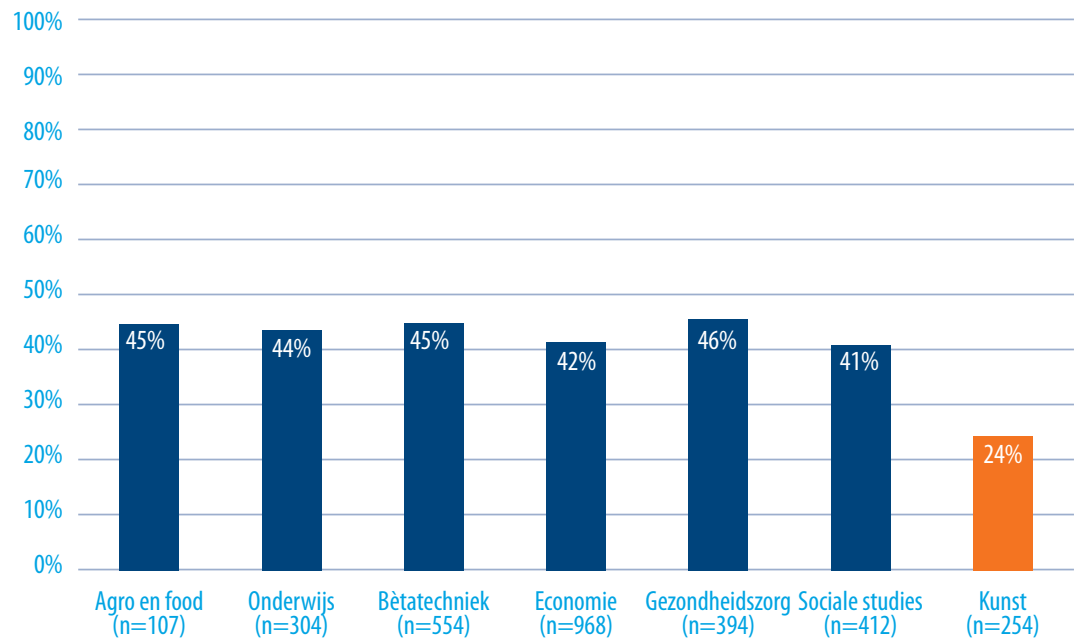


Binnen de kunstenopleidingen zijn er behoorlijke verschillen tussen de subsectoren waarneembaar (Figuur 3.5). Alumni uit de subsector Theater zijn relatief vaak tevreden over de voorbereiding op de loopbaan (32\%), hoewel nog altijd een derde hier ontevreden over is. Ook alumni uit de Overige Opleidingen laten weer een lastig te duiden, maar relatief positief beeld zien.

FIGUUR 3.5 Tevredenheid over studie ter voorbereiding op (verdere) loopbaan, in 2015, naar subsector, voltijd $(n=254)$

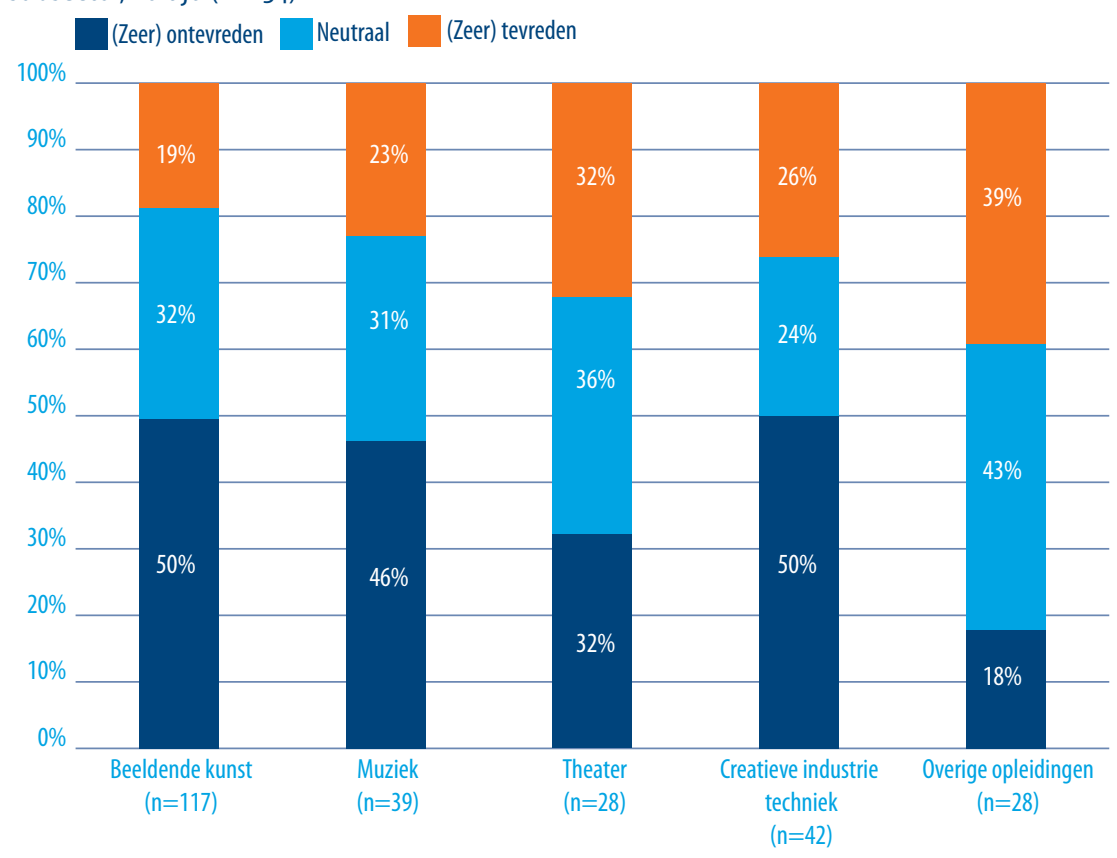

\subsection{Opnieuw kiezen voor opleiding}

Zowel één jaar na afstuderen als vijf/zes jaar na afstuderen zijn alumni uit de kunstensector gevraagd of ze, alles overziend, opnieuw voor de gevolgde hbo-opleiding zou kiezen. Het aandeel dat hier opnieuw voor zou kiezen is over de periode gedaald van 85 procent naar 77 procent. Ondanks deze daling zou nog altijd drie kwart van de afgestudeerden dezelfde opleidingskeuze hebben gemaakt. Deze daling in het percentage blijkt volledig toe te schrijven aan een daling onder de voltijdstudenten. In Figuur 3.6 is te zien dat het aandeel dat opnieuw voor de opleiding binnen deze groep daalde van 84 procent naar 76 procent. Onder deeltijdstudenten is het aandeel gelijk gebleven (86\%).

De daling onder voltijdstudenten is niet per se negatief. Het is immers 'natuurlijk' dat naarmate men ouder wordt, men meer reflecteert op de gemaakte keuzes en meer bewust wordt van de keuzes die men had kunnen maken. Het feit dat deeltijders eerder vasthouden aan hun oorspronkelijke positieve oordeel over de gemaakte keuze is consi- 
stent hiermee. Zij hebben meestal meer werkervaringen achter de rug, en een deel van hen zal bovendien voor de opleiding hebben gekozen om een nieuwe draai aan de loopbaan te geven (bijvoorbeeld kansenvergroting).

FIGUUR 3.6 Zou achteraf opnieuw voor de gevolgde hbo-opleiding kiezen, in 2010-2011 en 2015, naar voltijd en deeltijd $(n=279)$

2010-2011 2015

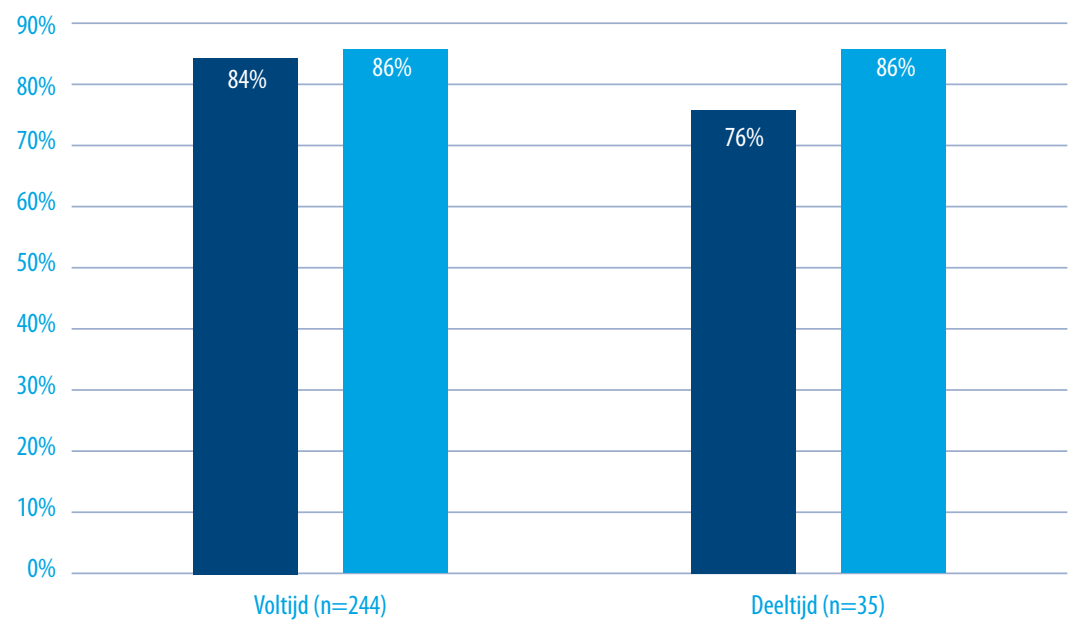

Het aandeel afgestudeerden aan de kunstenopleidingen dat opnieuw voor de gevolgde opleiding zou kiezen daalde per saldo met 8 procentpunt. Er waren echter veel meer alumni die tussen 2010/2011 en 2015 van mening zijn veranderd. Dit is te zien in Figuur 3.7: er zijn zowel verschuiven van 'wél naar niét opnieuw voor opleiding kiezen' geweest, als van 'niét naar wél.' Van degenen die één jaar na afstuderen aangaven opnieuw voor de opleiding te kiezen, geeft 15 procent vijf/zes jaar na afstuderen aan dit inmiddels niet meer te doen. Andersom geeft 35 procent van degenen die één jaar na afstuderen nít opnieuw voor de opleiding zouden kiezen, vijf/zes jaar na diplomering tóch aan hier opnieuw voor te kiezen. Deze verschuivingen laten zien dat nieuwe ervaringen (onder meer op de arbeidsmarkt) en voortschrijdende kennis over de jaren tot andere inzichten kunnen leiden. 
FIGUUR 3.7 Zou achteraf opnieuw voor de gevolgde hbo-opleiding kiezen in 2015, naar antwoord

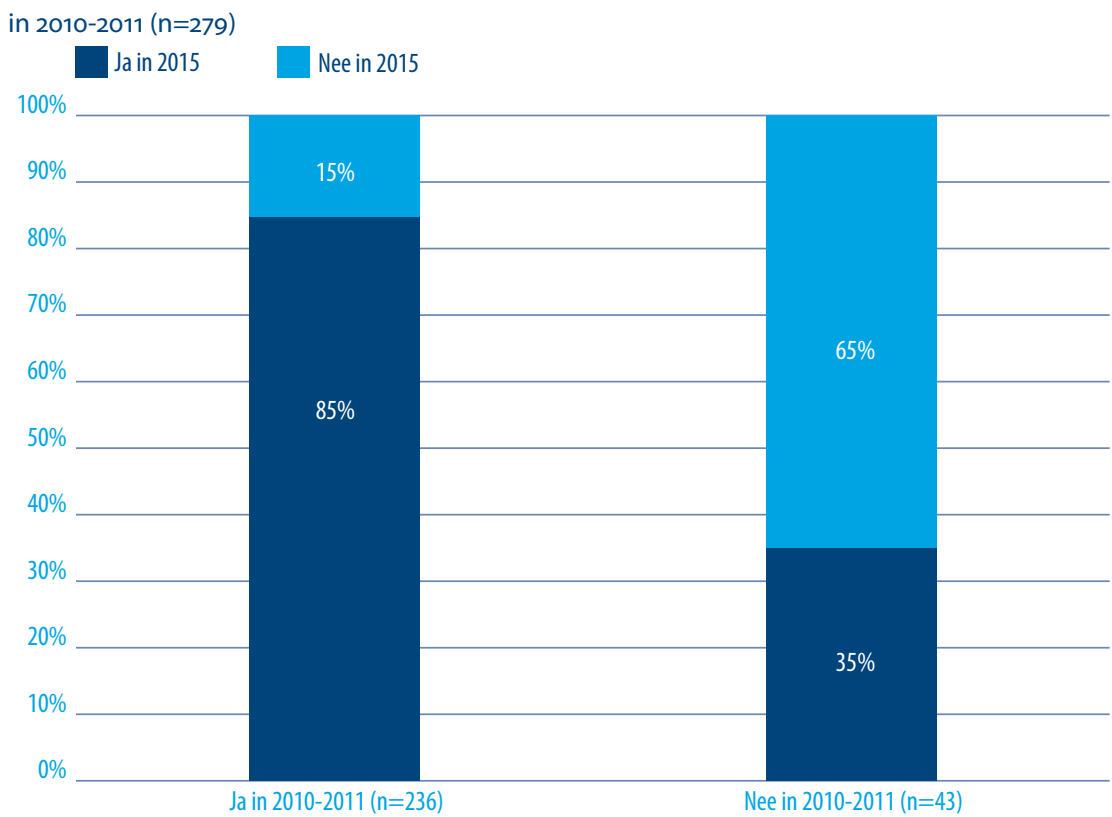

In Figuur 3.8 zien we voor de verschillende hbo-sectoren het aandeel (voltijd) afgestudeerden dat in 2010/2011 en/of in 2015 opnieuw voor de gevolgde opleiding zou kiezen. Zowel in 2010/2011 als in 2015 ligt het percentage voor de sector Kunst iets boven het hbo-brede gemiddelde van respectievelijk 80 procent en 74 procent. We zien dat er binnen alle sectoren sprake is van een daling in het percentage 'herkiezers'. De daling is het sterkst binnen de sectoren Economie, Sociale Studies en Kunst. Het hoogste percentage afgestudeerden dat opnieuw voor de opleiding zou kiezen vinden we (op beide meetmomenten) binnen de sectoren Onderwijs en Gezondheidzorg.

Tot slot tonen we in Figuur 3.9 het aandeel afgestudeerden dat opnieuw voor de gevolgde opleiding zou kiezen, gespecificeerd naar de subsectoren binnen de Kunst. Ook hier zien we een structurele daling in het aandeel alumni dat opnieuw voor dezelfde opleiding zou kiezen. Zowel één jaar als vijf/zes jaar na diplomering zouden afgestudeerden uit de subsector Muziek het vaakst opnieuw voor de opleiding kiezen, het betreft respectievelijk een zeer hoge 95 procent en 86 procent. Alumni van de Theater-opleidingen zouden minder vaak opnieuw voor de opleiding kiezen, respectievelijk 70 procent en 63 procent. 
FIGUUR 3.8 Zou achteraf opnieuw voor de gevolgde hbo-opleiding kiezen, in 2010-2011 en 2015, naar hbo-sector, voltijd $(\mathrm{n}=2936)$

2010-2011 2015

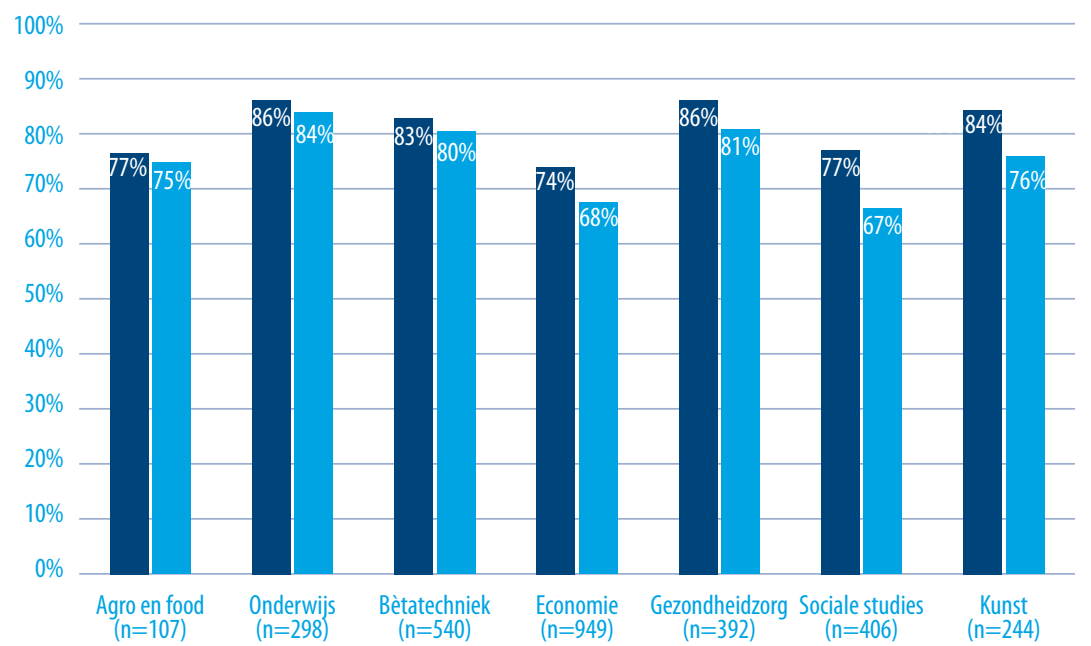

FIGUUR 3.9 Zou achteraf opnieuw voor de gevolgde hbo-opleiding kiezen, in 2010-2011 en 2015, naar subsector, voltijd $(n=244)$

2010-2011 2015

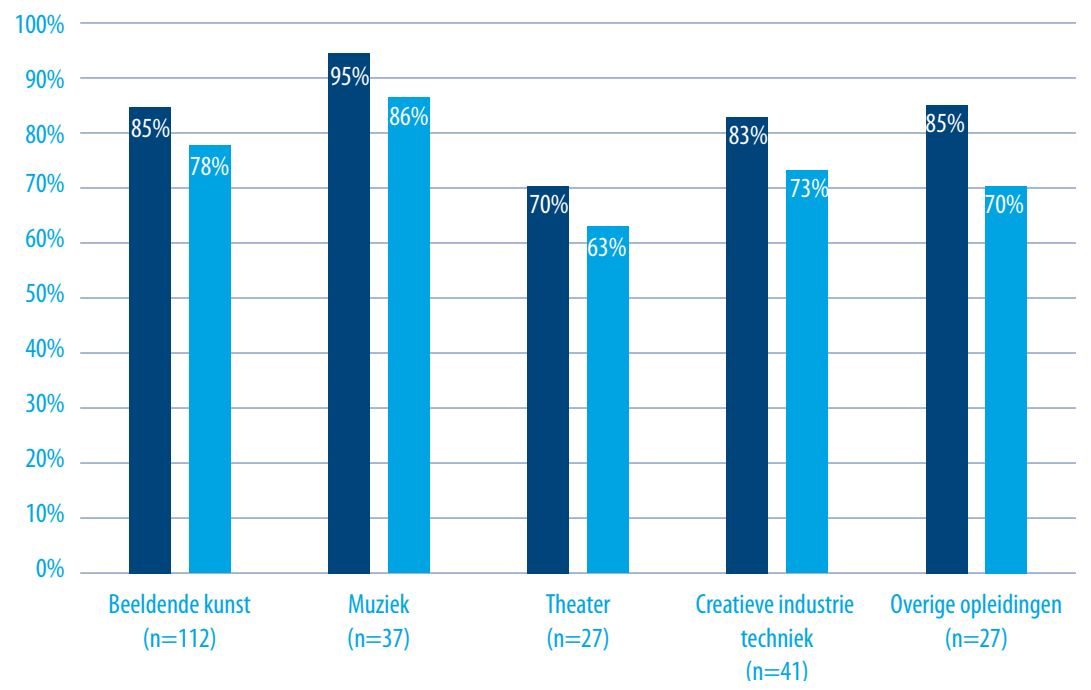





\section{CONCLUSIES}

In voorliggende rapportage is de arbeidsmarktpositie van afgestudeerde kunstenaars en hun terugblik op de gevolgde hbo-opleiding vijf c.q. zes jaar na diplomering in kaart gebracht. Bovendien is de situatie vijf/zes jaar na diplomering (anno 2015), waar mogelijk, gerelateerd aan de situatie van deze groep afgestudeerden één jaar na diplomering (2010/2011). Uit dit onderzoek volgt dat de arbeidsmarktpositie kort na afstuderen deels samenhangt met de situatie vijf/zes jaar na afstuderen, maar dat de beginsituatie zeker niet determinerend is voor de verdere loopbaan.

Een stroeve arbeidsmarktintrede heeft lang niet altijd nadelige gevolgen voor de verdere loopbaan. Ruim de helft van de afgestudeerde kunstenaars die een jaar na diplomering een baan onder hbo-niveau hadden, werkt vijf/zes jaar na afstuderen toch in een baan op het eigen opleidingsniveau. Andersom zijn er ook alumni die vijf/zes jaar na afstuderen juist een zwakkere arbeidsmarktpositie hebben ingenomen. Zo is de werkloosheid tussen 2010/2011 en 2015 toegenomen van 3 procent naar 6 procent, hetgeen gezien de forse cultuurbezuinigingen in de afgelopen jaren (en de daarmee gepaard gaande banenkrimp) niet onverwacht is.

Gegeven deze moeilijke periode voor de cultuursector is het des te opvallender dat de arbeidsmarktpositie van de meeste afgestudeerde kunstenaars tussen 2010/2011 en 2015 juist flink versterkt is. Het aandeel alumni dat werkzaam is op hbo-niveau nam toe met 6 procentpunt (van $72 \%$ naar $78 \%$ ), en het aandeel dat werkzaam is in het 'kerndomein' (d.w.z. een baan in de eigen opleidingsrichting én op het eigen opleidingsniveau) nam zelfs toe met 10 procentpunt (van 53\% naar 63\%). Ook de lonen van de afgestudeerden groeiden fors: vijf/zes jaar na diplomering verdienen zij (gemiddeld) ongeveer een kwart meer dan één jaar na afstuderen.

Afgestudeerde kunstenaars ervaren in 2015 (vijf/zes jaar na diplomering) relatief goede loopbaanmogelijkheden. De helft van de voltijdstudenten geeft aan goede carrièremogelijkheden te hebben in de huidige baan: dit is boven het hbo-brede gemiddelde van 43 procent. Onder deeltijdstudenten is men iets minder positief over de carrièremogelijkheden. Ook de baantevredenheid ligt verhoudingsgewijs hoog. Sterker nog: alumni uit de kunstensector (voltijd) zijn van alle hbo-sectoren het vaakst tevreden over hun huidige baan (68\% tegenover $63 \%$ hbo-breed). 
Alumni van de kunstenopleidingen kijken over het algemeen positief terug op hun studie. In 2015 geven twee op de drie afgestudeerden aan (zeer) tevreden te zijn over de gevolgde opleiding. Dit is vergelijkbaar met het hbo-brede gemiddelde. Over de voorbereiding van de studie op de loopbaan is men echter kritisch: minder dan drie tiende van de alumni is hier tevreden over. Dit aandeel ligt daarmee fors lager dan hbo-breed (aldaar ruim vier tiende). Desalniettemin geven drie op de vier afgestudeerde kunstenaars in 2015 aan nog altijd voor de opleiding te zullen kiezen, als zij opnieuw voor de beslissing zouden staan. 